\title{
DISCLAMMER
}

This report wes preparod as an wcoomt of work eponsored by an areacy of the United States Governmeat. Neither the Uaited States Goverament nor any acency thereof, nor any of their capployees, mekes any warranty, exprese or inplied, or asumes any lezal liability or reapoasibility for the accuracy, completeeses, or usefuleses of any information, apparatus, product, or procews dieclowed, or reproweats that its we would not infringe privately owned rights. Referance hervin to any apecific commercial product, proces, or service by trade name, trademark, innufecturer, or otherwise does not mecesesrily constitute or imply its endorsement, recommadstion, or favoring by the United States Government or any agency thereof. The views and opinions of authon expresend berain do not necessarily state or teflect those of the United Stace Gowernment or any aneacy thereof.

UCRL--53631

DE86 013226

\section{Reaction of Topopah Spring Tuff with J-13 Water: A Geochemical Modeling Approach Using the EQ3/6 Reaction Path Code}

\author{
Joan M. Delany
}

Manuscript date: November 25, 1985

\section{LAWRENCE LIVERMORE NATIONAL LABORATORY University of California - Livermore, California - 94550}


CONTENTS

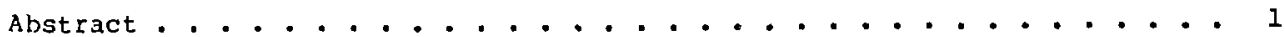

1. Introduction ............................ 1

2. EQ3/6 Software Package . . . . . . . . . . . . . . . . . . 3

3. Characterization of Water from Well J-13 . . . . . . . . . . . 5

4. Bulk Mineralogy of the Topopah Spring Tuff . . . . . . . . . . . 7

5. Code Input Parameters . . . . . . . . . . . . . . . . . 10

A. EQ3R . . . . . . . . . . . . . . . . . . . . . 10

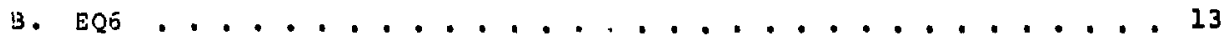

6. EQ6 Simulations . . . . . . . . . . . . . . . . . . . . 20

A. $150^{\circ} \mathrm{C}$ Core-Wafer simulation . . . . . . . . . . . . . 21

B. $250^{\circ} \mathrm{C}$ Core-wafer simulation . . . . . . . . . . . . . . . . 24

C. $150^{\circ} \mathrm{C}$ Crushed-Tuff simulation . . . . . . . . . . . . . . 26

D. $150^{\circ} \mathrm{C}$ Open-System Application Representing Repository Conditions . 27

7. Summary . . . . . . . . . . . . . . . . . . . . . . 31

8. Bibliography . . . . . . . . . . . . . . . . . . . . . 33

Appendix A. Constants Used to Construct Theor tical Rock Recipes . . . . 39

AppendiX B. Sample EQJNR Input File of J-13 Water . . . . . . . . . . 41

Appendix C. Sample EQS INPUT File for Core-wafer Experiments . . . . . 43 
REACTION OF TOPOPAH SPRING TUFF WITH J-13 WATER:

A GEOCHEMICAL MODELING APPROACH USING THE EQ3/6 REACTION PATH CODE

\section{ABSTRACT}

The $8 Q 3 / 6$ geochemical modeling code package was used to investigate the interaction of the Topopah Spring Tuff and J-13 water at high temperafures. $\mathrm{EQ}_{\mathrm{3}} / 6$ input parameters were obtained from the regults of laboratory experiments using USW G-1 core and J-13 water. Laboratory experiments were run at 150 and $250^{\circ} \mathrm{C}$ for 66 days using both wafer-size and crushed tuff. EQ3/6 modeling reproduced results of the $150^{\circ} \mathrm{C}$ experiments except for a small increase in the concentration of potassium that occurs in the first few days of the experiments. At $250^{\circ} \mathrm{C}$, the EQ3/6 modeling reproduced the major water/rock reactions except for a small increase in potassium, similar to that noted above, and an overall increase in aluminum. The increase in potassium concentration cannot be explained at this time, but the increase in $A 1$ concentration is believed to be caused by the lack of thermodynamic data in the EQ3/6 data base for dachiardite, a zeolite observed as a run product at $250^{\circ} \mathrm{C}$. The ability to reproduce the majority of the experimental rock/water interactions at $150^{\circ} \mathrm{C}$ validates the use of $\mathrm{EQ} 3 / 6$ as a geochemical modeling tool that can be used to theoretically investigate physical/chemical environments in support of the Waste Package Task of NNWSI.

\section{INTRODUCTION}

The Nevada Nuclear Waste Storage Investigations (NNWSI) project is part of the U.S. Department of Energy's Civilian Radioactive Waste Management (CRWM) program. Currently the NNWSI project is supporting development of the EQ3/6 geochemical modeling code package under the Geochemistry subtask in order to meet the geochemical modeling needs of the NNWSI project. EQ3/6 will be used to model the complex chemical interactions between groundwater and the repository host rock, and to evaluate the geochemical effects of the potential 
migration of radionuclides into the water table and the accessible environment. The potential repository horizon under investigation by the NNWSI project is a welded, devitrified tufE located beneath Yucca mountain and situated above the water table in the unsaturated zone (Vieth, 1982). This document describes an application of the EQ3/6 codes to help evaluate chemical reactions occurring in closed-system high-temperature experiments. These results can also be used as a validation case as defined by silling (1983) for the $\mathrm{EQ} 3 / 6$ software package.

Since oxidizing conditions are expected to be present in the unsaturated zone in Yucca Mountain (Roseboom, 1983; Wollenberg et al., 1983), the exchange of $\mathrm{O}_{2}$ and $\mathrm{CO}_{2}$ can be simulated by extending the modeling of the closed-system experiments to an open-system model using the recent extended capabilities of the BQ6 code (Delany and Wolery, 1384). Tne unsaturated zone can be conceptualized as a large external reservoir containing $\mathrm{O}_{2}$ and $\mathrm{CO}_{2}$ at fixed fugacities: as these gases are consumed by reactions in the waste package environment, they may be replenished from this reservoir.

Since 1982, the Topopah spring Member of the Paintbrush Tuff has been targeted as the potential repository horizon. $J-13$, the nearest producing well from this horizon is used by the NNWSI program to represent groundwater of the surrounding aquifer. The interaction between Topopah spring Tuff (Tpt) and $\mathrm{J}-13$ water is modeled as the reaction of an aqueous solution in contact with a specific mineral assemblage. Full petrologic and mineralogic descriptions of the host rock have been published for both outcrop and drill core samples (see Knauss, 1984b, for review). The proposed repository horizon is a phenocryst-poor, densely welded and devitrified tuff. The bulk-rock mineralogy of the Topopah spring can be represented as an assemblage of cristobalite, alkali feldspar, and quartz with minor biotite, plagioclase, and montmorillonite (waters and Carroll, 1981; warren et al., 1984). Theoretical host-rock recipes have been constructed using estimates of the volume percent of the major phases and the measured porosity of the core wafer. Analyses of natural $\mathrm{J}-13$ water serve as direct ingut for the composition of the initial fluid. The rock and water compositions are then reacted using the EQ6 reaction path code at the temperature of the experiment for the designated time interval. The secondary reaction products produced by the EQ6 code are compared with those that have been observed for the core-wafer experiments. Because a negligible fraction of the solid samples appears to have reacted, 
the concentrations of the major cations in solution are a much more sensitive measure of the tuff/water reaction that had occurred. It is not possible to analyze the alteration products of the crushed-tuff experiments in corresponding detail; however, if good agreement is found between the progressive changes in tha theoretical and analytical solution compositions, the EQ6 results are intespreted to predict the secondary alteration that may form in these experiments.

The modeling of experimental results is an important EQ3/6 application for the NNWSI project. The flexible nature of the $8 Q 3 / 6$ package lends itself to modeling the controlled conditions of laboratory experiments. Certain conditions can then be relaxed or modified to Investigate similar environments that would occur in nature at depths and conditions expected in the near - and far-field repository regimes. For example, water in a closed-system experiment can be easily transformed to water in the unsaturated zone that is in contact with the atmosphere by exercising the EQG NFFG option that can fix the $\mathrm{O}_{2}$ and $\mathrm{CO}_{2}$ fugacities to constant values.

\section{EQ3/6 SOFTWARE PACXAGE}

The EQ3/6 package is composed of two large FORTRAN computer codes, EQ3NR and EQ6, which are supported by a common thermodynamic data base. EQ3NR is a speciation-solubility code that computes a model of the state of an aqueous solution. Input can be direct analytical measurements along with a number of imposed reaction constraints. EQ3NR produces the distribution of aqueous sr. 2 es, their thermodynamic activities and saturation indices for various solids.

The EQ6 computer code is a part of the EQ3/6 software package (Wolery, 1979, 1983, 1985a, 1985b; Wolery et al., 1984) that can be used to compute models of the evolution of aqueous geochemical systems (such evolution is often referred to as a reaction path). Calculations can be carried out for systems that are either open or closed to the atmosphere. The EQ6 reaction-path code calculates changes in rock/water systems as reactions proceed toward a state of overall chemical equilibrium. EQ6 is initialized by attaching a description of the aqueous solution, generated by EQ3NR as a PICKUP file, and a set of irreversible components that are to react as the 
reaction progresses. Users specify the kinetic rate laws describing the dissolution of these phases.

The thermodynamic data are processed through a FORTRAN code, MCRT, that checks for thermodynamic consistency, extrapolates heat capacity functions with temperature, and generates data blocks for insertion into the master EQ3/6 thermodynamic data file, DATAO. MCRT contains an internal data base of free energies and enthalpies of formation, third law entropies, and heat capacities of specified reactions that are commonly used in geochemical calculations. The thermodynamic data in DATAO are processed through an additional FORTRAN code, EQTL, that checks for mass and charge balance, fits all data to a predetermined temperature grid, and writes the data files that are read directly by the $E_{Q} 3 \mathrm{NR}$ and $\mathrm{E}_{\mathrm{Q}} 6$ source cores. The number of species in the Lawrence Livermore National Laboratory (LLNL) data base is constantly growing, and the data base is in a continual state of development in order to make the thermodynamic data as complete and accurate as possible. The EQ3/6 data base work will be under constant documentation for the next few years; all modeling runs employed the most current version of the data base DATAOS 25 idated $2 / 21 / 85)$.

All calculations used $E Q 3 / 6$ version $3230 \mathrm{~B}$ (released $4 / 2 / 84$ ). The kinetic rate laws available in the this release version of EQ6 provide only for Aissolution reactions. The $3230 \mathrm{~B}$ version represents precipitation as an instantaneous process governed by solubility equilibrium. Once saturation of a reactant occurs, its dissolution rate is set to zero. The incorporation of precipitation rate laws as a function of reaction progress and time is currently in progress and will be available in the next release version of the EQ3/6 software package expecter in early 1986 [see Delany et al. (1986) for a description of the precipitation kinetics option].

The geochemical environment to be modeled is defined as a system closed to the atmosphere, although the fluid phase is initially saturated with $\mathrm{CO}_{2}$ from its contact with the atmospheric levels of $\mathrm{CO}_{2}$ that is present in its groundwater source. This simulates a natural aqueous system which forms a closed system at depth. Since $\mathrm{CO}_{2}$ and $\mathrm{O}_{2}$ are two of the principal geochemical weathering agents, the primary process controlling the evolution of the solution compositions in these experiments is mineral dissolution. The solution cation compositions show minor yet reproducible changes over the duration of the experiments. 


\section{CHARACTERIZATION OF WATER FROM WELL J-13}

The NNWSI program uses water-supply well J-13 to support all activities at Yucca Mountain. J-13 is the nearest producing well to Yucca Mountain and is frequently pumped to supply drilling water for test holes in the area. Most rock/water laboratory experiments by supporting NNWSI programs use it as the representative groundwater. The well was originally designated usGs Test Well 6 1963, and is located in the sw corner of Jackass Flats in Forty-Mile Wash at $N 749,209$ and $E 579,651$ (Nevada state Central zone coordinates). The major nroducing horizon is a highly fractured interval within the Topopah spring Member of the Paintbrush Tuff at a depth of $728 \mathrm{~m}$ (Robison, 1984). J-13 groundwater analyses have been reported in numerous publications both by the USGS and the NNWSI program (Claassen, 1973, 1983; wolfsberg et al., 1979; Daniels et al., 1982; Guzowski et al., 1983; Benson et al., 1983; Thordarson, 1983; Moore et al., 1984; Ogard and Kerrisk, 1984).

J-13 groundwater can be classified as sodium bicarbonate type. The bulk chemistry of the groundwater reflects high concentrations of silica, sodium, and bicarbonate ion. Similar characteristics have been shown to be related to the alteration of volcanic rocks at Rainier Mesa (Claassen and White, 1979; White, 1979; White and Claassen, 1979; White et al., 1980; White and Claassen, 1980). Ogard and Kerrisk (1984) discuss the similarity between relative cation and anion compositions among groundwaters from tuffaceous aquifers at Rainier Mesa, Pahute Mesa, and Yucca Mountain. The range of compositions is consistent with the precipitation of silica, clays, and zeolites as secondary phases.

The J-13 laboratory supply, used in all rock-water experiments at LLNL, is stored on site in a plastic lined 55-galion drum filled directly at the well. The laboratory supply has been well characterized by oversby and knauss (1983), Knauss (1984a), and Oversby (1984a, 1984b). Table 1 lists an average composition (compiled over a 12-month period) of the LLNL J-13 laboratory supply. Comparison with other published analyses of J-13 water that has not undergone long-term storage indicates that the storage conditions do not significantly affect the overall composition. Dissolved oxygen content and $\mathrm{pH}$ reported from well head measurements are 5.5 and $7.1 \mathrm{ppm}$, respectively (Daniels et al., 1982). Dissolved oxygen measurements made on the laboratory supply after standing for several months, indicate that the storage tank has become 
Table 1. Average $J-13$ fluid analysis for LLNL. laboratory supply.

\begin{tabular}{|c|c|c|}
\hline $\mathrm{pH}$ & Component & Concentration $(\mathrm{mg} / \mathrm{L})$ \\
\hline \multicolumn{3}{|c|}{7.6} \\
\hline & Li & 0.042 \\
\hline & $\mathrm{Na}$ & 43.9 \\
\hline & $k$ & 5.11 \\
\hline & $\mathrm{Ca}$ & 12.5 \\
\hline & $\mathrm{Mg}$ & 1.92 \\
\hline & $\mathbf{s r}$ & 0.035 \\
\hline & A 1 & 0.012 \\
\hline & $\mathrm{Fe}$ & 0.006 \\
\hline & Si & 27.0 \\
\hline & $\mathrm{NO}_{3}$ & 9.6 \\
\hline & $\mathbf{F}$ & 2.2 \\
\hline & $\mathrm{Cl}$ & 6.9 \\
\hline & $\mathrm{HCO}_{3}$ & 125.3 \\
\hline & $\mathrm{SO}_{4}$ & 18.7 \\
\hline
\end{tabular}

saturated with oxygen $(8.1 \mathrm{mg} / \mathrm{L})$ and the $\mathrm{pH}$ has risen to an average value of 7.6. The rise in $\mathrm{pH}$ is consistent with the loss of $\mathrm{CO}_{2}(\mathrm{~g})$ as the storage tank is slowly emptied.

All chemical analyses are checked for electrical neutrality before they are considered as valid data for modeling work. The percentage electrical imbalance is computed from the total aqueous speciation model of the solution generated by EQ3NR. All evaluations of the quality of water analyses calculated using the principle of electrical neutrality should be done using the total aqueous speciation model. Consideration of the speciation of only the major ions can yield different results. The condition of electroneutrality in a fluid is defined by equivalent sums of positive and negative charges

$\sum M_{\text {cat }^{2}}{ }_{\text {cat }}=\sum M_{a n}{ }^{2} a n$ 
. Where $M$ and $z$ are the molality and ionic charge, respectively, of the subscripted cation and anion species. The most common equation used to calculate the percent error is given by Freeze and cherry (1979) as:

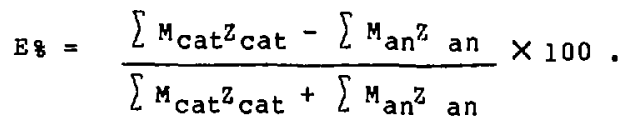

Five percent is generally considered the acceptable level of maximum imbalance for most groundwater studies. Geochemical codes often calculate the residual imbalance with slightly different forsis of $\mathrm{Eq}$. (2). Subtle computational differences can result in computed error differences of a couple of percent. Therefore, the quality of an analysis may vary between acceptable and unacceptable depending on the equation used. For instance, EQ3NR (version $3230 \mathrm{~B}$ ) uses $\mathrm{Eq}$. (3) with the assumption that cation analyses tend to be more accurate and complete than anion analyses. This assumption is especially valid for many older groundwater analyses existing in the published literature.

$E_{8}=\frac{\sum M_{M_{c a t}}{ }^{Z} \text { cat }-\sum M_{a n^{Z}} \text { an }}{2 \sum M_{\text {cat }}{ }_{\text {cat }}} \times 100$.

Accordingly, the basis may be better defined as twice the sum of the cation concentrations. It should be noted that the factor of 2 was omitted from this equation in the version $3230 \mathrm{~B}$ release of the EQ3NR code. In this study, the electrical neutrality of all solutions was determined using Eu. (3), and an error of less than 38 was routine $3 y$ computed for individual J-13 analyses. The average $\mathrm{J}-13$ analysis is thought to closely represent the laboratory supply on any given day.

\section{BULK MINERALOGY OF THE TOPOPAH SPRING TUFE}

The core wafers and crushed samples used in the water-rock experiments are from drill hole usw G-l at a depth of $1232 \mathrm{ft}$, which is within the potential repository interval (Tyler, 1982). These samples are densely welded and showed some evidence of vapor phase crystallization. The major phenocrysts are alkali feldspar and plagioclase, with biotite being found as an accessory mineral, and minor montmorillonite disseminated throughout the ground mass. Warren et al. (1984) found that the compositions of major 
phenocrysts in the Topopah spring determined by electron microprobe analyses vary with each characteristic tuff unit. 'iherefore, the analytic compositions and bulk volume estimates of the major phases used in the host-rock recipes were obtained from an average of quantitative estimates that have been made from petrographic and $x$-ray diffraction observation on the proposed repository interval from USW-Gl core samples (warren et al., 1984). The host rock can be adequately represented by six mineral phases: cristobalite, sanidine, quartz, along with minor plagioclase, montmorillonite, and biotite. The three major phases comprise approximately 98 of the rock. The compositions of sanidine, plagioclase, and blotite are represented as binary and ternary solid solution compositions in the host-rock recipes. The montmorillonite' composition present in the proposed repository interval has not been determined analytically, although an analysis has been reported of a sample of nearly puce montmorillonite from the Grouse Canyon Member of the Belted Range Tuff, which underlies the Paintbrush Tuff at Rainier Mesa (Claassen and white, 1979). The molecular fu.mula of this sample is:

$\mathrm{Na} .06^{\mathrm{K}} .06^{\mathrm{H}} .09^{\mathrm{Mg}} .43^{\mathrm{Ca}} \cdot 17^{\mathrm{Fe}}{ }_{.03}^{2+} \mathrm{Fe}^{3+} .15^{\mathrm{Al}} 1.44^{\mathrm{Ti}} \cdot 01^{\mathrm{Si}} 3.92^{\mathrm{O}} \mathrm{O}^{(\mathrm{OH})_{2}}{ }^{\circ}$

This phase is represented in the EQ3/6 data base by Mg-beidellite whose composition is:

$\mathrm{Mg}_{0.165} \mathrm{Al}_{2} \mathrm{Al}_{0.33^{\mathrm{Si}}} \mathrm{S}_{3.67} \mathrm{O}_{10}(\mathrm{OH})_{2}$.

All smectites in the EQ3/6 data base are idealized end-member compositions that rarely coincide with the compositions of naturally occurring phases. Mg-beidellite was used because it takes account of the major cation concentration in the chemical formula given above. Table 2 summarizes the major phases.

Preparation of the crushed rock and core-wafer samples was similar to that described by Knauss (1984b) and Knauss and Beiriger (1984a) for outcrop samples of Tpt used in waste package experiments. The crushed samples were dry sieved to a size range of 75 to $150 \mathrm{im}$. These samples were not washed and probably contain fine particulate matter that has been reported to contribute to higher dissolution rates at onset-of-dissolution experiments (cf. Holdren and Berner, 1979). The core-wafer samples were cut, polished, thoroughly washed in distilled water, then cleaned in an ultrasonic bath to 
Table 2. Composition of Topopah Spring Tuff.

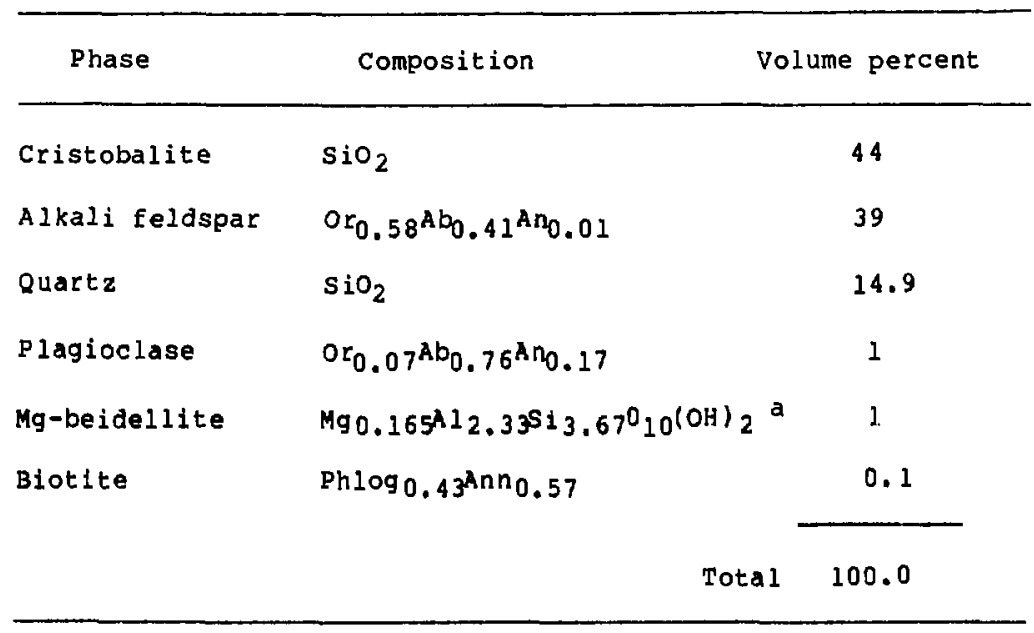

a EQ3/6 model composition, not based on petrographic observations.

remove all microparticulate matter from the surfaces. The effective porosity of the core-wafer sample is 6.58 using a measured bulk density of 2.335 $\mathrm{g} / \mathrm{cm}^{3}$ and a grain density of $2.522 \mathrm{~g} / \mathrm{cm}^{3}$ (Knauss et al., 1985b). The sum of the densities of the major mineral phases $\left(\rho_{i}\right)$ multiplied by their respective volume percentage estimates $\left(v_{i}\right)$ give a theoretical grain denisity for the rock:

$\rho_{\text {rock }}=\frac{\sum v_{i} \rho_{i}}{1008}$.

Using Eg. (4) with the data from Table 2 and Appendix $A$ yields a value of $2.487 \mathrm{~g} / \mathrm{cm}^{3}$. The reasonable agreement between the measured and calculated grain densities provides a helpful indication that the average Tpt rock composition in Table 2 is an adequate representation of the rock samples used in the experiments. BET Ar measurements yield surface areas of $2.67 \mathrm{~m}^{2} / \mathrm{g}$ and $0.378 \mathrm{~m}^{2} / \mathrm{g}$ for the crushed and core-wafer samples, respectively. 
A. $E Q 3 N R$

EQ3NR serves to evaluate all laboratory analyses, equilibrated at $25^{\circ} \mathrm{C}$ and saturated with oxygen. EQ3NR results are used to make sure that all analyses satisfy charge-balance constraints, as discussed above. This procerice ensures that only good quality analyses are used both dis starting $\mathrm{J}-13$ compositions and as the experimental solution compositions that are to be modeled. The initial J-13 solution composition for each water-rock model has to be created using EQ3NR. Certain constrainic must be imposed on tho laboratory analysis to generate a solution composition that most closely reproduces the chemical state of the groundwater. Water analyses from well $\mathrm{J}-13$ and analyses from other wells in the surrounding area indicate much higher silica concentrations are found in these waters than is usually associated with wormal groundwaters (Davis, 1964). These high silica concentrations are associated with groundwaters leaching volcanjc glass (White, 1979; White et al., 1980). In order to maintain EQ3/C silica concentrations that are compatible with observed concentrations, silica phases more stable than $\alpha$-cristobalite (including guartz) are suppressed using the NXMOD option. This option allows the solurion to supersaturate with respect to the specified phases.

Volcanic-glass leaching experiments on rock samples from Rainier Mesa indicate that groundwaters in a similar environment to the $\mathrm{J}-13$ locality are in equilibrium with a clay phase, possibly montmorillonite (white and Claassen, 1979, 1980). Mineral stability diagrisis serve to illustrate these equilibrium conditions for J-13 groundwater. These diagrams are usually constructed with the thermodynamic properties of pure minerals rather than the actual compositions of phases present in the host rock; yet they provide useful estimates of general equilibrium relations and have been shown to give a reasonable approximation of observed phases in groundwater systems.

Groundwater compositions from most environments are found to be in equilibrium with k3olinite at $25^{\circ} \mathrm{C}$ (Davis, 1964). The high silica concentration in $\mathrm{J}-13$ water puts analyses of both field and laboratory samples outside the stability field of kaolinite and into a montmorillonite stability field. Figure 1 depicts phase relations for the system $\mathrm{K}_{2} \mathrm{O}-\mathrm{Al} \mathrm{I}_{2} \mathrm{O}_{3}-\mathrm{SiO}_{2} \mathrm{H}_{2} \mathrm{O}$ 


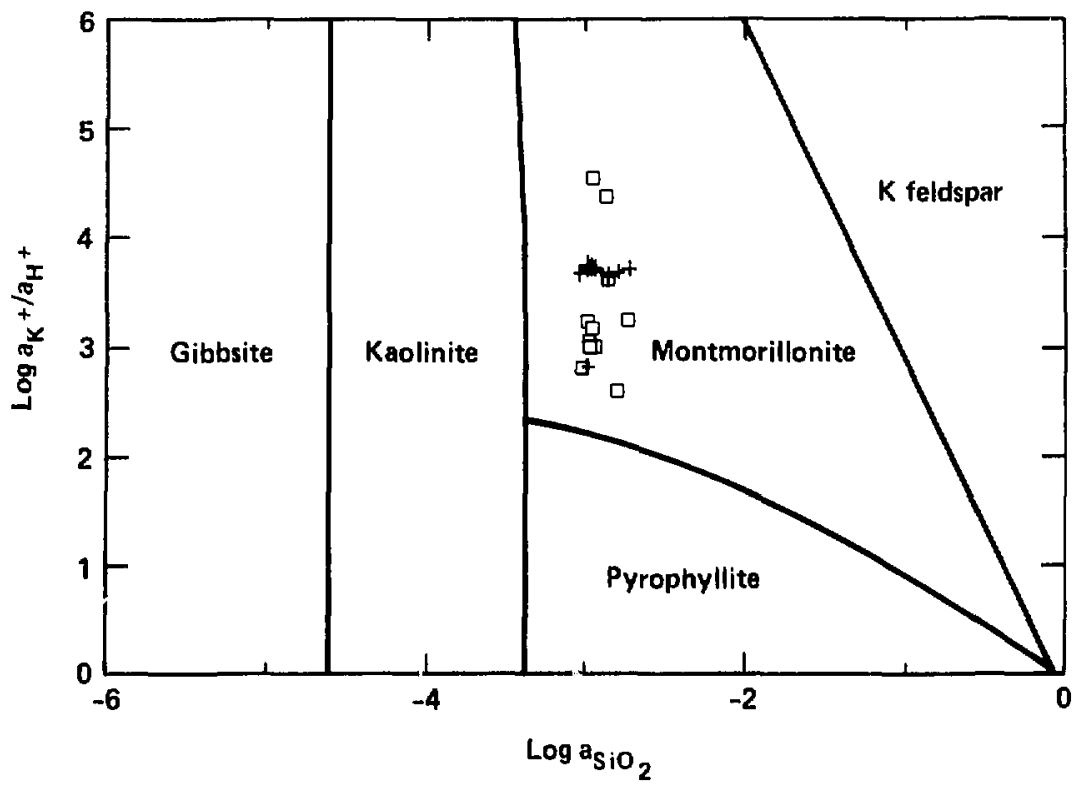

Figure 1. Log activity plot of potassium vs aqueous silica at $25^{\circ} \mathrm{C}$ (see tex:). The open squares represent $J-13$ compositions from various literature sources. The crosses represent concentration: of the LLNL laboratory suppli.

at $25^{\circ} \mathrm{C}$. The stability fields for gibbsite, kaolinite, pyrophyllite, and $K$ feldspar were computed from the thermodynamic data in the EQ3/6 data base. The boundary of the montmorillonite stability field was generated using the equations given by Aagard and Helgeson (1983), and the thermodynamic data for

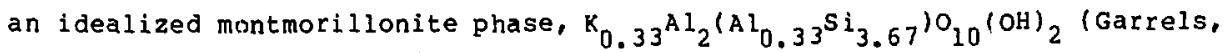
1984). The montmorillonite composition used by Garrels (1984) is similar to the idealized compositions in the EQ3/6 data base.

At elevated temperatures, the stability field for kaolinite shifts to higher silica activities. At $150^{\circ} \mathrm{C}$, the phase relations indicate that $\mathrm{J}-13$ water is in equilibrium with kaolinite. Figure 2 shows the ohase relations at $150^{\circ} \mathrm{C}$ for the $\mathrm{Na}_{2} \mathrm{O}-\mathrm{Al} 2_{2} \mathrm{O}_{3}-\mathrm{SiO}_{2}-\mathrm{H}_{2} \mathrm{O}$ system as a function of sodium concentration (the principal cation in J-13 water). A similar activity diagram constructed using phase relations at $250^{\circ} \mathrm{C}$ indicates that the $\mathrm{J}-13$ analyses at $250^{\circ} \mathrm{C}$ are equilibrated with pyrophylite.

In the EQ3NR model, the aluminum concentration in $\mathrm{J}-13$ was set to satisfy equilibrium with kaolinite. This was done because the analytical 


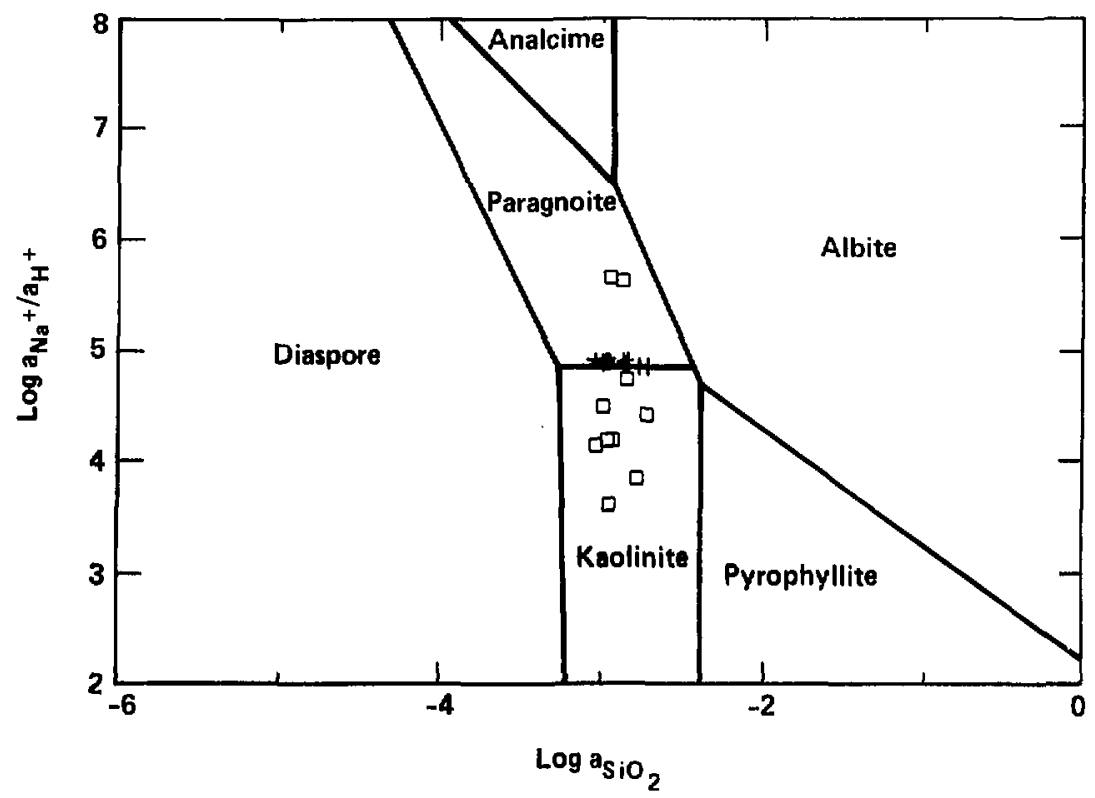

Figure 2. Log activity plot of sodium vs aqueous silica at $150^{\circ} \mathrm{C}$. See Fig. 1 for symbol explanation.

concentration was thought to be unreliable due to the lack of adequate filtering techniques. This constraint reduced the number of aluminosilicate phases (either saturated or supersaturated) computed by EQ3NR as present in J-13 water. Rock/water systems generally contain aluminum in low concentrations. As a conservative component it is readily incorporated into aluminosilicates, and, therefore, present at low levels in solution. The EQ3NR speciation model of $J-13$ generated with the above geochemical constraints converged in 18 iterations and required a total time of $4.8 \mathrm{sec}$ ( $4.2 \mathrm{cpu}$ ) of CDC 7600 computer time. Similar constraints are added to all $\mathrm{J}-13$ analyses when generating starting solutions to be used in EQ6 reaction-path modeling runs that involve the reaction of $\mathrm{J}-13$ water with Topopah Spring host rock. Appendix B gives a complete EQ3NR input file for $\mathrm{J}-13$.

Preliminary rock/water interaction experiments were done at LLNL using J-13 water and the Bullfrog Member of the Crater Flat Tuff. Although these experiments were carried out at $150^{\circ} \mathrm{C}$ for periods of up to 60 days, the overall solution effects were small loversby and Knauss, 1983; Knauss, 1984a). To most accurately model the small variations in solution 
compositions expected in later experiments with Tpt, individual $\mathrm{J}-13$ water compositions analyzed at the start of each experiment were used for the initial input. An individual $\mathrm{J}-13$ analysis (DB800), used for the $150^{\circ} \mathrm{C}$ for the $150^{\circ} \mathrm{C}$ core-wafer experiments shown in Appendix B, can be compared with the average composition shown in Table 1 .

B. EQ6

The EQ6 code simulates the closed-system experiments of the reaction of the host rock with $J-13$ water at the desired temperature. For each phase listed above, a reactant block containing the following information is entered on the EQ6 INPUT file: the JCODE Elag Indlcating whether the composition of each phase is to be expressed as a pure minecal or a solid solution, the initial number of moles of reactant (MORR), the surface-area optIon (NSK), the total surface area (SK) in $\mathrm{cm}^{2}$, the ratio of kinetically active surface area to total surface area (FK), a rate law selection parameter (NRK), and the associated rate law constants (RK1, RK2, RK3). In order to express the reactant concentrations of the mineral phases as molal concentrations per kilogram of solution, theoretical rock-sample recipes were constructed for the crushed tuff and polished core-wafer experiments as follows:

1. For each subscripted mineral phase, the volume percent estimate $\left(v_{i} z\right)$ from Table 2 is converted to weight percentage $\left(n_{i} z\right)$ using the relationship

$n_{i} z=\frac{v_{i} \rho_{i}}{\rho_{\text {rock }}}$.

Here $\rho_{i}$ is the specific density of the particular phase and $\rho_{\text {rock }}$ is the bulk densit $;$ of the host rock. The total volume percent for the core-wafer recipe is less than $100 \%$, because it takes into account the measured porosity of the sample. The amount of cristobalite was reduced by an amount equal to the measured effective porosity.

2. The weight percent estimate of each phase is related to the total mass of some volume of rock by

$$
n_{i}{ }^{8}=\frac{100 n_{i}}{n_{\text {rock }}} .
$$


If a specific mass of $1 \mathrm{~g}$ of rock is assumed, the weight percent estimates are easily converted to moles of reactant per $g$ of rock using the data given in Appendix A.

3. Multiplying the moles of reactant per $g$ of rock by the rock/water ratio (scaled to one kilogram of solution) yields the actual mass of each phase.

4. The bulk surface area $\left(\mathrm{cm}^{2} / \mathrm{g}\right)$ of each host-rock sample is measured by the BET Ar method. This measurement is then transformed inco an estimate of specific surface area for each component phase by assuming the relative proportion of each phase equals its volume percentage. The volume percent estimated for the core-wafer samples takes into account the sample porosity so must be normalized to 100 in order to correctly equate the total surface area with the sum of the component specific surface areas.

5. The specific surface areas estimated above in units of $\mathrm{cm}^{2}$ per $g$ of rock are converted to reactant surface area estimates. Each reactant (SK) is multiplied by the corresponding sample mass per $\mathrm{kg}$ of solution.

Tables $3 a$ and $3 b$ list the $E Q 6$ rock-sample recipes for both the crushed and core-wafer samples. These recipes were generated using the data j.n Table 2 and Appendix $A$.

In cider to simulate the closed-system environment of the experimental apparatus and to relate the extent of host-rock dissolution to the actual time of the experiments, the EQ6 kinetic model option is used (IOPTl=1). This option permics mineral dissolution kinetics to be calculated for each reactant. EQ6 has incorporated rate law expressions that represent forms to which experimental data can be fit as a function of time. The most common rate equation for describing silicate dissolution processes is based on transition-state theory (see Lasaga, 1981; Helgeson et al., 1984; Wolery, 1986). The equation used to calculate actual rates in EQ6 consistent with transition-ctate theory is

$\left.v=\zeta \leq k+11-\exp \left(-\frac{A}{\sigma R T}\right)\right]$

where $v$ is the net reaction vejocity as a function of time, $\zeta$ is a norinalizing factor that represents the ratio of effective to total surface area, $s$ is total surface area, $k$ is the rate constant in mol $/ \mathrm{cm}^{2}$ " $s e c, A$ is the thermodynamic affinity, $R$ is the gas constant, $T$ is absolute temperature, and $\sigma$ is a kinetic stoichimetric factor (usually unity, see wolery, 1986 ). 
Table 3a. EQ6 rock recipe for crushed Topopah Spring Tuff.

\begin{tabular}{|c|c|c|c|c|c|c|c|}
\hline \multirow[b]{2}{*}{ Phase } & \multirow{2}{*}{$\begin{array}{l}\text { Weight } \\
\text { percent }\end{array}$} & & \multicolumn{3}{|c|}{ Moles of reactant } & \multicolumn{2}{|c|}{ Specific surface area } \\
\hline & & & (mol & (g) & MORR & $\left(\mathrm{cm}^{2} / \mathrm{g}\right)$ & SK \\
\hline Cristobalite & 41.3 & $x$ & 6.874 & $10^{-3}$ & $2.387 \times 10^{-1}$ & 11748 & 407914 \\
\hline Alkali feldspar & 40.5 & $x$ & 1.490 & $10^{-3}$ & $5.174 \times 10^{-2}$ & 10413 & 361560 \\
\hline Quartz & 15.9 & $x$ & 2.646 & $10^{-3}$ & $9.188 \times 10^{-2}$ & 3978.3 & 138135 \\
\hline Plagioclase & 1.06 & $x$ & 3.983 & $10^{-5}$ & $1.383 \times 10^{-3}$ & 267 & 9271 \\
\hline Mg-beidellite & 1.14 & $x$ & 3.110 & $10^{-5}$ & $1.080 \times 10^{-3}$ & 267 & 9271 \\
\hline Biotite & 0.12 & $x$ & 2.547 & $10^{-6}$ & $8.844 \times 10^{-5}$ & 26.7 & 927 \\
\hline
\end{tabular}

Table 3b. EQ6 rock recipe for G-1 Topopah spring Tuff core wafer .

\begin{tabular}{|c|c|c|c|c|c|c|c|}
\hline \multirow[b]{2}{*}{ Phase } & \multirow{2}{*}{$\begin{array}{l}\text { Weight } \\
\text { percent }\end{array}$} & \multicolumn{4}{|c|}{ Moles of reactant ${ }^{b}$} & \multicolumn{2}{|c|}{ Specific surface area ${ }^{c}$} \\
\hline & & (mo & $\operatorname{le}(9)$ & & ORR & $\left(\mathrm{cm}^{2} / \mathrm{g}\right)$ & sK \\
\hline Cristobalite & 37.5 & 6.241 & $\times 1.0^{-3}$ & 6.663 & $\times 10^{-2}$ & 1516.2 & 16178 \\
\hline Alkali feldspar & 43.14 & 1.587 & $\times 10^{-3}$ & 1.694 & $\times 10^{-2}$ & 1576.6 & 16822 \\
\hline Quartz & 16.9 & 2.813 & $\times 10^{-3}$ & 3.003 & $x 10^{-2}$ & 602.5 & 6429 \\
\hline Plagioclase & 1.13 & 4.246 & $\times 10^{-5}$ & 4.533 & $\times 10^{-4}$ & 40.45 & 432 \\
\hline Mg-beidellite & 1.21 & 3.301 & $x 10^{-5}$ & 3.522 & $\times 10^{-4}$ & 40.45 & 432 \\
\hline Biotite & 0.13 & 2.759 & $\times 10^{-6}$ & 2.946 & $\times 10^{-5}$ & 3.8 & 40.5 \\
\hline
\end{tabular}

\footnotetext{
a Bulk density $=2.335 \mathrm{~g} / \mathrm{cm}^{3}$.

$b$ Mass of core wafer $=2.2496 \mathrm{~g}$, sample volume $=210.7 \mathrm{~g}$.

C BET Ar surface area $=0.378 \mathrm{~m}^{2} / \mathrm{g}$.
} 
The $\zeta$ term in Eq. (7) takes into account the ambiguity that arises from using rate constants that have been determined experimentally. Such rate constants are usually computed from a quantity that is actually the product of the rate constant and surface area. Since BET techniques usually give the total surface area, the rate constants are generally calculated from it. Aside from the fact that measured surface areas show a lot of variability, rate constants determined this way are based on the assumption that the active surface area is the total surface area. If a value is assigned to $\zeta$ that is less than unity, then either of the following assumptions can be made: (1) the total active surface area(s) has been overestimated, or (2) the rate constant has been overestimated.

A value for $\zeta$ is input for each reactant in the EQ6 input file. This value has been used to denote the fraction of the total surface area that is estimated to be involved in the actual dissolution reactions. All reactants have the same value of $\zeta$ for each EQ6 run. As discussed below, there are significant differences between the core-wafer and crushed-tuff runs.

Dissolution rate constants consistent with transition-state theory have been reported for temperatures as high as $150^{\circ} \mathrm{C}$ only for $k$ feldspar (Helgeson et al., 1984) and the silica phases (Rimstidt and Barnes, 1980). Dissolution experiments of pure albite at $70^{\circ} \mathrm{C}$ (Knauss and wolery, 1985) and phlogopite at $25^{\circ} \mathrm{C}$ (Lin and Clemency, 1981) have yielded rate constants for plagioclase and mica, respectively. Temperature-dependent estimates were made from the measured rate constants were made by assuming constant activation energy.

Another form of Eg. (7) consistent with transition-state theory is $k^{\prime} r=A e^{-E / R T}$,

where $k^{\prime}$ is the rate constant at some elevated temperature in mol/cm "sec, $E_{a}$ is the activation energy, $R$ is the gas constant, and $T$ is the temperature of interest. The pre-exponential factor, $A$, is computed from the experimentally determined rate constant, $k^{\prime}$, at the reference temperature, $r_{r}:$

$A=k \cdot e^{E / R T} r$

An average activation energy of $14 \mathrm{kcal}$ (Lasaga, 1981) was used to estimate the rate constants of plaçioclase and mica at 150 and $250^{\circ} \mathrm{C}$. A brief 
description of the EQ6 rate constant values for the phases using the transition-state rate law (NRK $=2$ ) is given below:

1) Silica phases: Dissolution rate constants for $\alpha$-cristobalite and quartz were calculatea at 150 and $250^{\circ} \mathrm{C}$ using the differential rate equations given for the respective phases by Rimstidt and Barnes (1980). Rate constants were $f$ it to the following form

$\log k^{\prime}=a+b T+c / T$,

where the constants $a, b$, and $c$ are $-0.963,0.0$, and -3392 for o-cristobalite and $1.174,-2.028 \times 10^{-3}$ and -4158 for quartz. It was found that the rate constants computed using $\mathrm{Eq}$. (10) had to be adjusted slightly in order to reproduce the actual silica concentrations observed in solution at 150 and $250^{\circ} \mathrm{C}$. Preliminary EQ6 modeling runs indicated that this was necessary because the aqueous silica concentration was a primary factor in controlling the formation of secondary phases. Rate constant values of $3.55 \times 10^{-13}$ and $1.20 \times 10^{-13} \mathrm{~mol} / \mathrm{cm}^{2}$. sec were used for $\alpha$-cristobalite and quartz at $150^{\circ} \mathrm{C}$. This adjustment required increasing the rate constants by a factor of 3. At $250^{\circ} \mathrm{C}$ a similar rate-constant adjustment was necessary, but in the opposite direction. A measured BET Ar surface area for quartz sand with a 125-to-1000-um particle size is $9.2 \times 10^{-2} \mathrm{~m}^{2} / \mathrm{g}$.

2) Sanidine: Dissolution rate constants for $k$-feldspar were calculated from the rate equations given by Helgeson et al. (1984). Ine rate constants for 150 and $250^{\circ} \mathrm{C}$ are $2.88 \times 10^{-14}$ and $2.46 \times 10^{-13} \mathrm{~mol} / \mathrm{cm}^{2} \cdot \mathrm{sec}$, respectively. These equations were generated by regression techniques based on geometrical estimates of total surface area and experimental rate data available in the literature. A zeduction of two orders of magnitude in these rate constants was necessary to constrain host-rock dissolution to less than if during the reaction interval (see discussion below).

3) Plagioclase: An experimentally determined rate constant of $k^{\prime}=7.9$ $\times 10^{-16} \mathrm{~mol} / \mathrm{cm}^{2} \cdot \mathrm{sec}$, determined at $70^{\circ} \mathrm{C}$ by knauss and wolery (1985) for the dissolution pure albite was used with Eqs. (8) and (4) to calculate temperature dependent rate constants at 150 and $250^{\circ} \mathrm{C}$. The albite was cbtained from Evje, Norway, and the samples were ground by a tungsten-carbide flat plate grinder to a 75-to-125-um particle size, then washed thoroughly to remove the ultrafine size fraction. The crushed samples were dissolved in 
buffered solutions with $\mathrm{pH}$ from 1 to 13 for 50 days in flow-thru cells. A surface area of $770 \mathrm{~cm}^{2} / \mathrm{g}$ was measured for the washed sample using BET Ar techniques.

4) Biotite: An experimental rate constant of $k^{\prime}=3.8 \times 10^{-17}$

mol $/ \mathrm{cm}^{2} \cdot \mathrm{sec}$ determined at $25^{\circ} \mathrm{C}$ by Lin and Clemency (1981) for phlogopite was used to calculate temperature-dependent rate constants at 150 and $250^{\circ} \mathrm{C}$ [Eqs, (8) and (9)]. The phlogopite from Madagascar was dry ground in a Waring blender then sieved to -400 mesh. The crushed sample was dissolved in deionized water saturated with $\mathrm{CO}_{2}$ for 42 days in conditions that simulated a closed system. A surface area of $3.77 \mathrm{~m}^{2} / \mathrm{g}$ was measured using the BET $\mathrm{N}_{2}$ technique.

Although it is difficult to evaluate the uncertainty that should realistically be associated with these values, a rough estimate can be made for quartz, Rimstidt and Barnes (1980) have generated rate equations for pure silica phases over a $0-t o-300^{\circ} \mathrm{C}$ temperature range. The equation for quartz is a least-squares regression of their experimental data along with other available experimental data from the literature. Comparing rate constant values for quartz computed at $105^{\circ} \mathrm{C}$ using the generalized least-squares equation with the specific values reported by Rimstidt and Barnes for their experiment $2 \mathrm{E}$ at $105^{\circ} \mathrm{C}$ reveals a difference of one and 2 half orders of magnitude (Delany et al., 1986). Because the two silica phases, quartz and cristobalite, represent more than 508 of the host rock, an adjustment of up to . 1.5 orders of magnitude in the rate constants that was necessary to fit the observed shape of the concentration vs time curves for agueous silica in the core-water experiments does not seem unreasonable. The reason that $r$ ate-constant adjustments needed to $\mathrm{fit}$ the experimental data at 150 and $250^{\circ} \mathrm{C}$ were in opposite directions is unclear. The least-squares regression probably overfit and underfit the experimental silica concentrations as a function of increasing temperature.

Detailed examination of the altered core-wafer samples (Knauss et al., $1985 \mathrm{~b})$ reveals that only minor dissolution of the host rock has occurred during the reaction interval at $150^{\circ} \mathrm{C}$. This suggests that the dissolution rates of the individual phases must be constrained to yield limited dissolution of the host rock. Therefore, although large errors may be associated with the rates of the individual phases, the dissolution of the host rock is an internal check in the overall EQ6 simulation. A 28 
weight change was observed in core wafers weighed before and after the $150^{\circ} \mathrm{C}$ experiments. A change of approximately 68 was observed in the core wafers associated in the $250^{\circ} \mathrm{C}$ experiments (Knauss et al., 1985b).

In order to constrain the EQ6 dissolution of the host rock phases to a couple of percent, it was necessary to reduce the specific surface area of each phase. As noted above, specific surface areas were calculated from a measured BET Ar absorption area of the bulk sample and the corresponding volume percent of each phase. BET techniques have been shown to overestimate the actual surface areas that interact with solutions (i.e., biogenic phases, Walter and Morse, 1985; and ceramic waste forms, oversby, 1982). The active surface area of each phase is related to its total BET surface area in EQ6 by a constant associated with the nature of the sample type. The specific surface area of the core-wafer phases was adjusted tc be 208 of the aET surface area. Similarly, the specific surface area of the crushed-tuff phases was found to be approximately 58 of the BET surface area. Similar results were found for biogenic samples, the highest BET surface areas tend to have a lower fraction of available surface area.

No experimental data are available on the dissolution of smectite phases. Temperatures on the order of $150^{\circ} \mathrm{C}$ or higher are outside the stability field for most clays, and represent conditions that can be roughly equated with low-temperature metamorphism. Under these conditions the total dissolution of smectite would likely occur. To simulate this effect, a linear rate law that provides for constant dissolution as a function of time (NRK=4) has been used. A rate calculated assuming that the phase dissolved within 25 days for both the crushed tuff and core-wafer recipes gave the best fit of the observed aluminum concentration in solution. The surface area flag (NSK) was set to unity for all reactants, so the surface area changes in proportion to the reactant mass.

The NMODL= 2 option simulates a closed-system environment. The experimental temperature, specified as TEMPCO, is held constant for the duration of the experiment. Although the experimental apparatus maintained a constant pressure of 50 bars, the EQ6 code does not provide for pressure corrections above the water-saturation curve. Thus, the $150^{\circ} \mathrm{C}$ models are run with a computed pressure of 4.8 bars and the $250^{\circ} \mathrm{C}$ models are run with 39.7 bars pressure. It is assumed that these small pressure differences will not affect any of the computed run results. The total run-time interval is 
identified by TSTRT and TIMEMX, set to 0 and 66 (70) days (the actual duration of each experiment), respectively. The number of print points is controlled by the KSPPMX variable; a value of 5 is used to obtain a large nuriber of points that can closely reproduce the observed curvature in the plots of solution concentration vs time. The kinetic model option, IOPTlxl, indicates that the dissolution rate laws selected for the reactants are expressed in real time. The solid solution option, IOPT4=1, is activated because at least one reactant composition is expressed as a solid solution. For the remaining EQ6 INPUT file options, the default values that are automatically inserted when a variable is read as a zero or a blank are adequate.

\section{EQ6 SIMULATIONS}

The dissolution of the Tpt in J-13 water is evaluated by comparing the concentrations of the major cation components in solution as a function of time with the analytical results obtained from the core-wafer experiments (Knauss et al., 1985b). The experimental points represent ionic concentrations at $1,2,4,8,16,48$, and 66 days. The precipitation of secondary phases by $E Q 6$ is then compared with the alteration observed on the core wafers after the experiments (Knauss et al., 1984, 1985b). Good agreement is observed between the EQ6 simulations and the actual solution compositions and the secondary mineral phases observed in the $150^{\circ} \mathrm{C}$ core-wafer experiments. These results are then compared with the secondary alteration that is observed at $250^{\circ} \mathrm{C}$ (Knauss and Beiriger, $1984 \mathrm{~b}$; Knauss et al., $1985 \mathrm{~b}$ ). In the crushed-tuff experiments the altered solids cannot be observed analytically, so the $150^{\circ} \mathrm{C}$ core-wafer $r$ uns are used to benchmark the crushed-tuff experiments (Knauss et al., 1985a). The. EQ6 rock/water simulations are run for a theoretical 70 days. After this length of time the irreversible reactions indicate that only a fraction of the host rock is actually destroyed. A change of approximately 28 was observed in the weights of the core wafers before and after the experiments. It should be noted that the secondary or alteration phases that form in the EQ6 equilibrium simulations are those that are thermodynamically most stable relative to the mineral compositions that are present in the supporting data base. 
The first step in the EQ6 modeling of the core wafer experiments was to fit the aqueous silica concentration to the observed values. The computed values of aqueous silica concentration using the $150^{\circ} \mathrm{C}$ rate constants for cristobalite and quartz reported by Rimstidt and Barnes (1980) were slightly lower than the experimental data for reaction times on the order of the first 20 days of the experiment. To compensate for this, the rate constant for cristobalite was increased by a factor of 3 . Making this adjustment corresponds to using a rate constant compatible with a value for $180^{\circ} \mathrm{C}$ calculated from the Rimstidt and Barnes temperature-dependent equatinn. To maintain consistency the rate constant for quartz was adjusted to the corresponding $180^{\circ} \mathrm{C}$ value. These values were adopted for the aissolution rate constants of all subsequent $150^{\circ} \mathrm{C}$ runs. Rimstidt and Barnes (1980) also observed the initial steep rise in the silica concentration in their experiments, which they attributed to the presence of a surface layer of a "disturbed material" that dissolves more rapidly than the bulk solid. The initial steep slope observed for silica is slightly underestimated by the rate constants in the EQ6 simulations Rimstidt and Barnes used the dissolution rate of the dicturbed layer to determine their rate constants after determining that both the disturbed layer and the bulk solid have nearly the same solubility. As the reaction progresses, and silisa in the host rock dissolves, the total concentration in solution approaches a constant value determined by the solubility of cristobalite at $150^{\circ} \mathrm{C}$ (Knauss et al., 1984 ).

After adjusting the silica rate constants for the experimental temperature, the rates of each of the reactant phases were studied to ensure that negligible dissolution of the host rock had occurred over the reaction interval. To maintain this constraint, the active surface area available for dissolution had to be reduced considerably from the BET measurements of total surface area. Twenty percent of the measured surface area was found to adequately constrain host rock dissolution to between 1 and 28. This constraint is entered on the $8 Q 6$ INPUT file as the ratio (FK) of kinetically active surface area to total surface area. Holdren and Berner (1979) have identified active kinetic sites on feldspar surfaces as etch pits and increased surface roughness, suggesting that the total surface area probably 
does not actively participate in the dissolution of a phase. Etch pits were developed on phenocrysts in $150^{\circ} \mathrm{C}$ experiment, suggesting that only a portion of the total surface area was active in the dissolution process (Knauss et al.. 1985b).

With these model constraints, the observed solution concentrations of most of the major cations could be reproduced with the EQ6 code (Figs. $3 a$ and $3 \mathrm{bl}$. The concentration of $\mathrm{Ca}$ decreased from a value of 13 to 6.5 almost instantaneously. This initial drop is caused by the formation of calcite, and a further decrease throughout the experiment is caused by the precipitation of Ca-smectite. The smectite formation also coincides with a drop in $A I$ concentration in the same interval. The $A i$ concentration in the quench fluids reaches a maximum value after a duration of five to eight days then levels of for the remainder of the experiment. This peak can be reproduced by assuming the variation in $A$ l concentration is controlled by the relatively rapid, complete dissolution over a 25-day interval of the montmorizlonite component present in the host rock. The overestimation in the $A l$ concentration probably results from substituting the actual montmorillonite phase with the more aluminum-rich beidellite phase in the EQ3/6 data base.

Following initial solution changes the concentrations of $\mathrm{Na}, \mathrm{Mg}$, and $\mathrm{K}$ are all shown to be relatively constant throughout the reaction interval. A sharp rise in $K$ concentration during the first few days of the experiment cannot be accounted for by the dissolution of the major potassium phase, sanidine. If the rate constant of sanidine is increased to account for this, both the potassium and aluminum concentrations increase to very high values. similar behavior was obnerved in the solution compositions of experiments using outcrop samples of Tpt and J-13 water (Oversby, 1984a, 1984b). In the case of the outcrop samples a soluble evaporite salt component was found that accounted for the increased concentration of $K$. In these experiments the core wafers were cut from drill core, where such a component would not be present. The sample preparation procedure also included a thorough washing step to remove any microparticulate matter that could adhere to the surfaces. The only other identified host-rock phase containing $K$ consists of a small amount of biotite that is not present in a large enough amount to account for the observed increase.

The computed EQ6 model can adeguately reproduce the solution compositions for a 70 -day interval at $150^{\circ} \mathrm{C}$. The observed secondary products were minor calcite and clay or illite. The EQ6 product phases are ca-smectite and a 


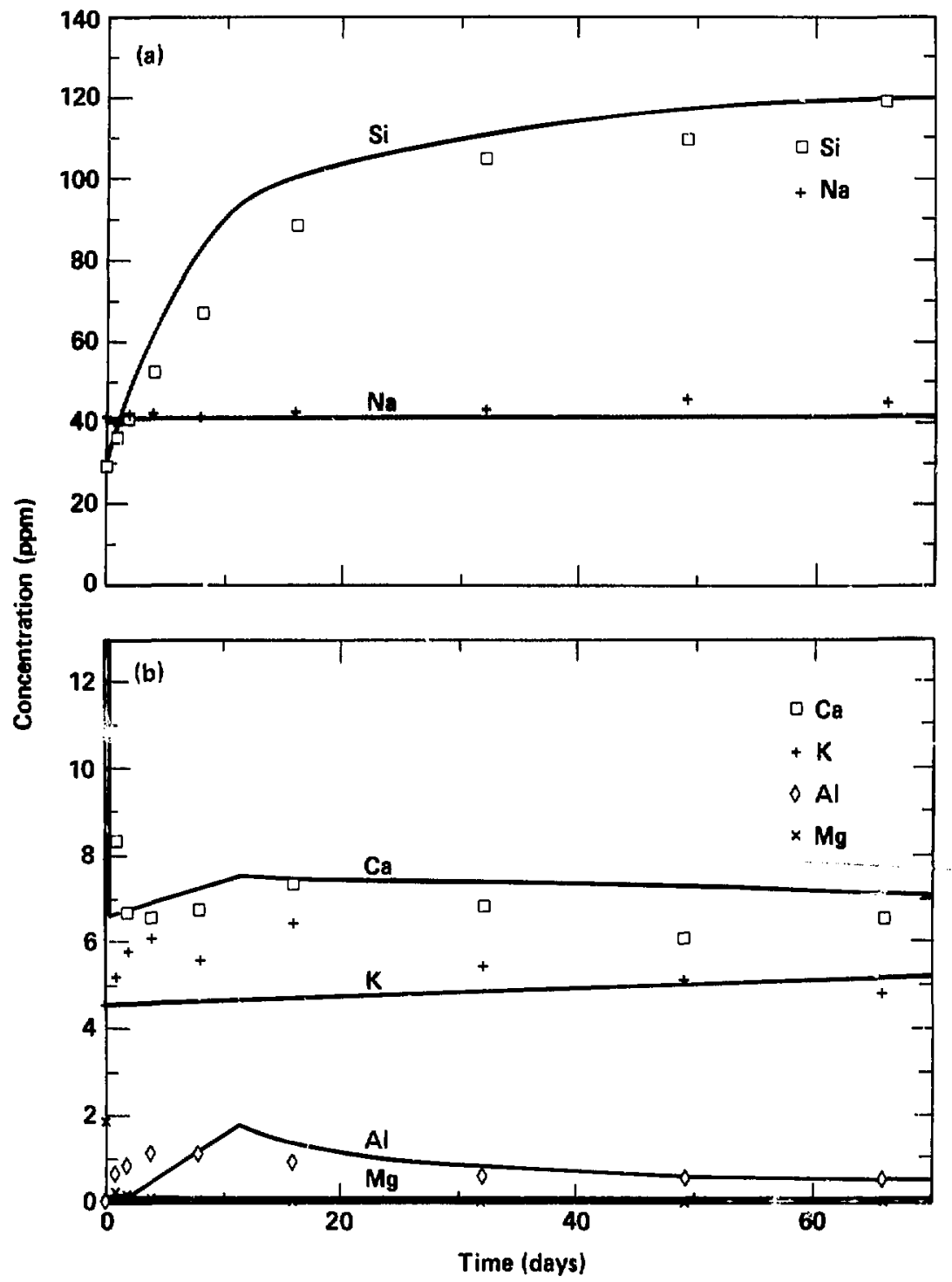

Figure 3a. Concentration of $\mathrm{Si}$ and $\mathrm{Na}$ us time for $150^{\circ} \mathrm{C}$ Topapah Spring Tuff (Tpt) core-wafer simulation. Symbols represent analytical values from knauss et al. (1985b). 3b. Concentration of $\mathrm{Ca}, \mathrm{K}, \mathrm{AI}$, and $\mathrm{Mg}$ vs time for $150^{\circ} \mathrm{C}$ Tpt core-wafer simulation. 
small amount of Ca-clinoptilolite. Although no zeolites have been observed petrographically by Knauss, it is not unreasonable to assume that a small amount of clinoptilolite may be present. In addition, it must be recognized that considerable uncertainty is generated by constraining the available mineral compositions to those in the $5,23 / 6$ data base. It is probably reasonable to assume that the secondary clay phase may be metastable and have precipitated quickly from solution. Metastable phases often have variable cation compositions, the result of phase precipitation in an ervironment where the composition of the solution is evolving as the reaction progresses.

\section{B. $250^{\circ} \mathrm{C}$ CORE-WAFER SIMULATION}

At higher temperatures, a significantly greater portion of the total surface area is expected to participate in kinttic reactions. It was found that the active surface area could be increased to as much as 508 of: the total surface area without dissolving an appreciable amount of the host rock. Increased reaction rates are observed and dissolution of the core wafer occurs much more rapidly. Cristobalite solubility (333 ppm) is reached in about 16 days (Fig. $4 \mathrm{a}$ ) in contrast to about 70 days at $150^{\circ} \mathrm{C}$ (Fig. $3 \mathrm{a}$ ). A much steeper initial rise in silica concentration is also observed at $250^{\circ} \mathrm{C}$ than at, $150^{\circ} \mathrm{C}$. Calcium exhibits the same instantaneous drop in concentration as observed at $150^{\circ} \mathrm{C}$ ex sept that the limiting value is much lower (approximately $2,0$ instead of $5.5 \mathrm{ppm})$. The drop is caused by the precipitution of calcite, and the amount precipitated in the $250^{\circ} \mathrm{C}$ run is largei than that produced in the $150^{\circ} \mathrm{C}$ run $6 y-a$ factor of 10 . The behaviors of $\mathrm{Na}, K$, and $\mathrm{Mg}$ are similar to those seen at lowemtemperatures.

The Al experimental concentration increases sharply to 3.5 ppm almost. instantaneously then levels off to a value around 2.0 after ajout five days (Fig. 4b). This behavior cannot be accounted for in the EQ6 simulation. The Al concentration continues to increase as a function of reaction progress to a maximum value of $16 \mathrm{ppm}$ at the end of the 66-day time interval. Ac $250^{\circ} \mathrm{C}$ there does not seem to be any EQ3/6 phase in competition for aluminum. The experimental data show a similar initial increase in $K$ concentration, although the model canriot account for it. 


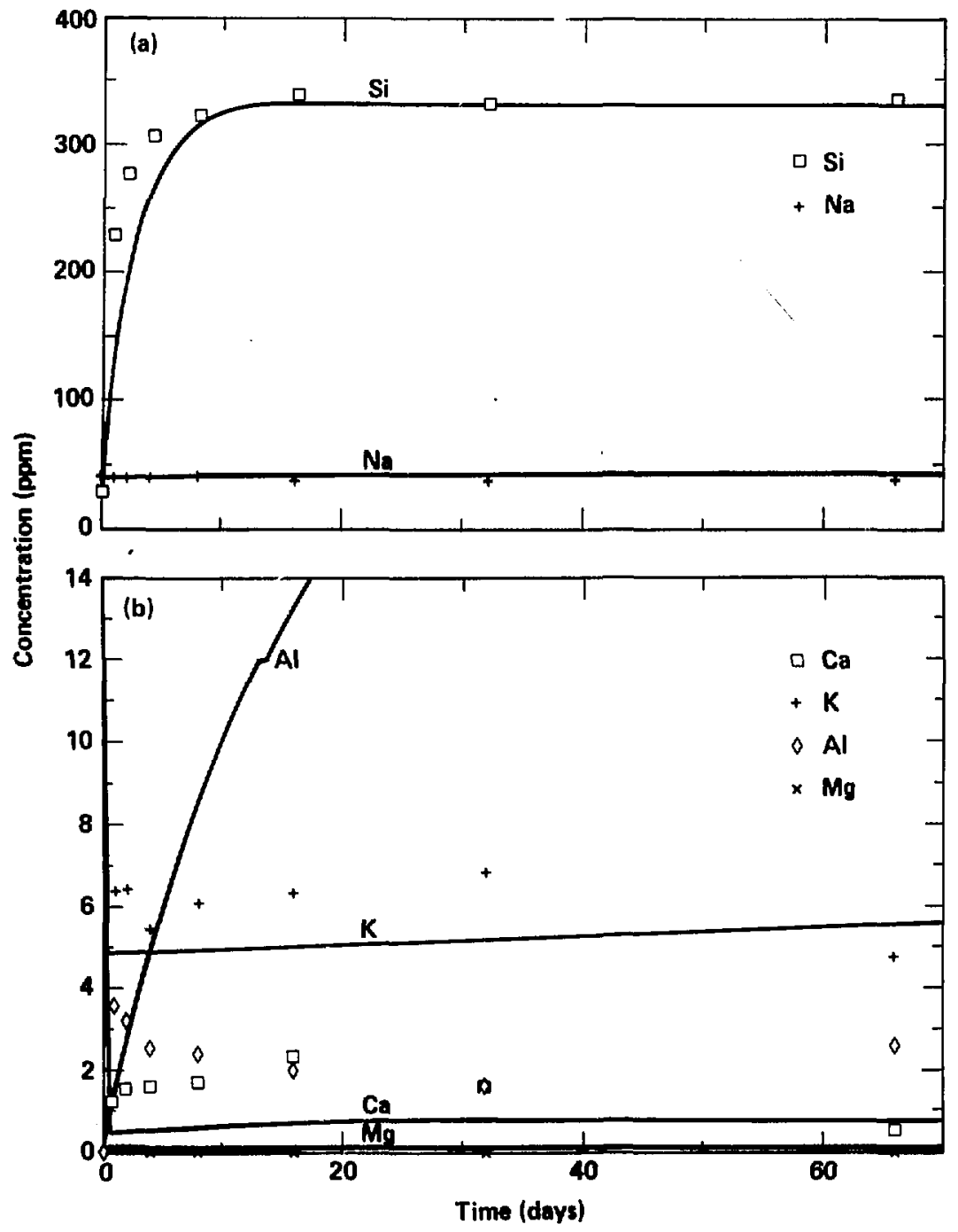

Figure 4a. Concentration of $\mathrm{Si}$ and $\mathrm{Na}$ vs time for $250^{\circ} \mathrm{C}$ Tpt core-wafer simulation. Symbols represent analytical values from Knauss et al. (1985b). 4b. Concentration of $\mathrm{Ca}, \mathrm{K}, \mathrm{Al}$, and $\mathrm{Mg} \mathrm{vs}$ time for $250^{\circ} \mathrm{C}$ Tpt core-wafer simulation. 
A major difference observed in the reacted $250^{\circ} \mathrm{C}$ core wafers is the appearance of the zeolite mineral, dachiardite. Dachiardite $\left[\mathrm{Ca}_{2.1} \mathrm{~K}_{0.34^{\mathrm{Na}}} 0.16\right.$

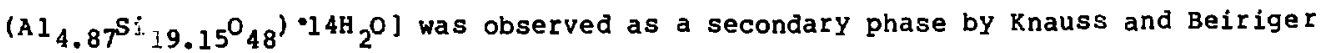
(1984b) in two separate experiments using both drillcore and outcrop tuff and J-13 water. This mineral is sufficiently rare that its structural parameters have yet to be determined, and no thermodynamic data are available. zeolitization that has been reported in portions of the Tpt is most commonly elinoptilolite. Estimated thermodynamic data have been entered on the $E Q 3 / 6$ data base for several common rock-forming zeolites (Kerrisk, 1983). It seems that although the $\mathrm{BQ6} 6$ model precipitates clinoptilolite as a secondary phase, its thermodynamic properties are not similar enough to those of dachiardite to serve as a comparable sink for aluminum. Dachiardite also would serve as a sink for $K$. Both $A l$ and $K$ concentration curves level off to constant values at approximately 12 days.

The reaction products generated by $\mathrm{EQ6}$ at the end of the $250^{\circ} \mathrm{C}$ cun are the same as those generated at the end of the $150^{\circ} \mathrm{C}$ run, except that the proportions of the minerals are reversed. At $250^{\circ} \mathrm{C}$ there is more ca-smectite and less clinoptilolite. This relationship is the opposite of that expected for increasing temperature. More complete data are needed for zeolite phases in order to determine modeling systems of this type at temperatures as high as $250^{\circ} \mathrm{C}$. For a repository at Yucca Mountain, $150^{\circ} \mathrm{C}$ is a reasonable upper bound for the temperature of liquid. Temperatures above $150^{\circ} \mathrm{C}$ are predicted to be extremely unlikely. Thus, the current $E Q 3 / 6$ data base would seem to be sufficient to model both the near- and far-field repository environment. Without additional data, this simulation suggests that perhaps a preliminary ceiling of $150^{\circ} \mathrm{C}$ should be imposed on EQ3/6 tuff/water applications.

\section{C. $150^{\circ} \mathrm{C}$ CRUSHED-TUFF SIMULATION}

The crushed-tuff simulation was modeled following much the same procedure as for the core wafer. Analysis of the solution compositions for the core-wafer and the crushed-tuff experiments suggests that they are very similar. This seens to indicate that despite the large increase in surface area, the host rock dissolves at $150^{\circ} \mathrm{C}$ by roughly the same amount. The kinetically active surface area can be determined for the crushed-tuff sample, if similar reaction results are assumed. This would indicate that 
approximately 58 of the total surface area of the crushed sample actually participates in the dissolution of the host rock. Because crushed samples were prepared by ixy grinding, a fraction of microparticulate matter would be expected to be present, causing increased dissolution rates at the early stages of the experiment.

This behavior is observed in the $\mathrm{Al}, \mathrm{K}$, and $\mathrm{SiO}_{2}$ concentrations (Fig. 5). The concentration of $A l$ can be accounted for by a more rapid dissolution of montmorillonite than was assumed for the core-wafer experiment. A value of one day was used; this was based on the assumption that the grinding process exposed all the montmorillonite in the sample as an active component. In contrast, the core wafer exposed only 20 of it. The steeper slope in the $\mathrm{SiO}_{2}$ curve can be accounted for by an increase in the rate for cristobalite in the crushed tuff sample. It seems that a larger effective surface area for cristobalite is avallable to react than exists for the other major phases in the crushed sample. This could result from the grinding process and may reflect the preferential exposure of the fine-grained nature of cristobalite. The EQ6 run products are the same as those observed in the $150^{\circ} \mathrm{C}$ core-wafer simulation. It is not possible to analyze the run products from the crushed-tuff experiments. The $\mathrm{QQ} 6$ results cannot be validated, although the solution compositions indicate that the reactions proceed to about the same degree of completion as those for the core-wafer experiments.

\section{D. $150^{\circ} \mathrm{C}$ OPEN-SYSTEK APPLICATION REPRESENTING REPOSITORY CONDITIONS}

The results of the $150^{\circ} \mathrm{C}$ core-wafer experiments were used to compute the extent of reaction that would occur if the same core wafer were reacted for 100 years. An additional constraint was imposed to simulate a system open to the atmosphere. The proposed repository will be situated at a depth of about $300 \mathrm{~m}$ below the surface in the unsaturated zone, we have extrapolated known EQ6 results by extending the range of the model's predictions to inc sude physical conditions that may be encountered in the environmert of the repository at Yucca Mountain. If the system is open to the atmosphere, the effect is to fix the fugacity of $\mathrm{CO}_{2}$ at $10^{-3.5}$ bar throughout the course of the reaction.

The evolution of the solution composition over a 100-year time interval shows that the system reaches a steady state at approximately 180 days 


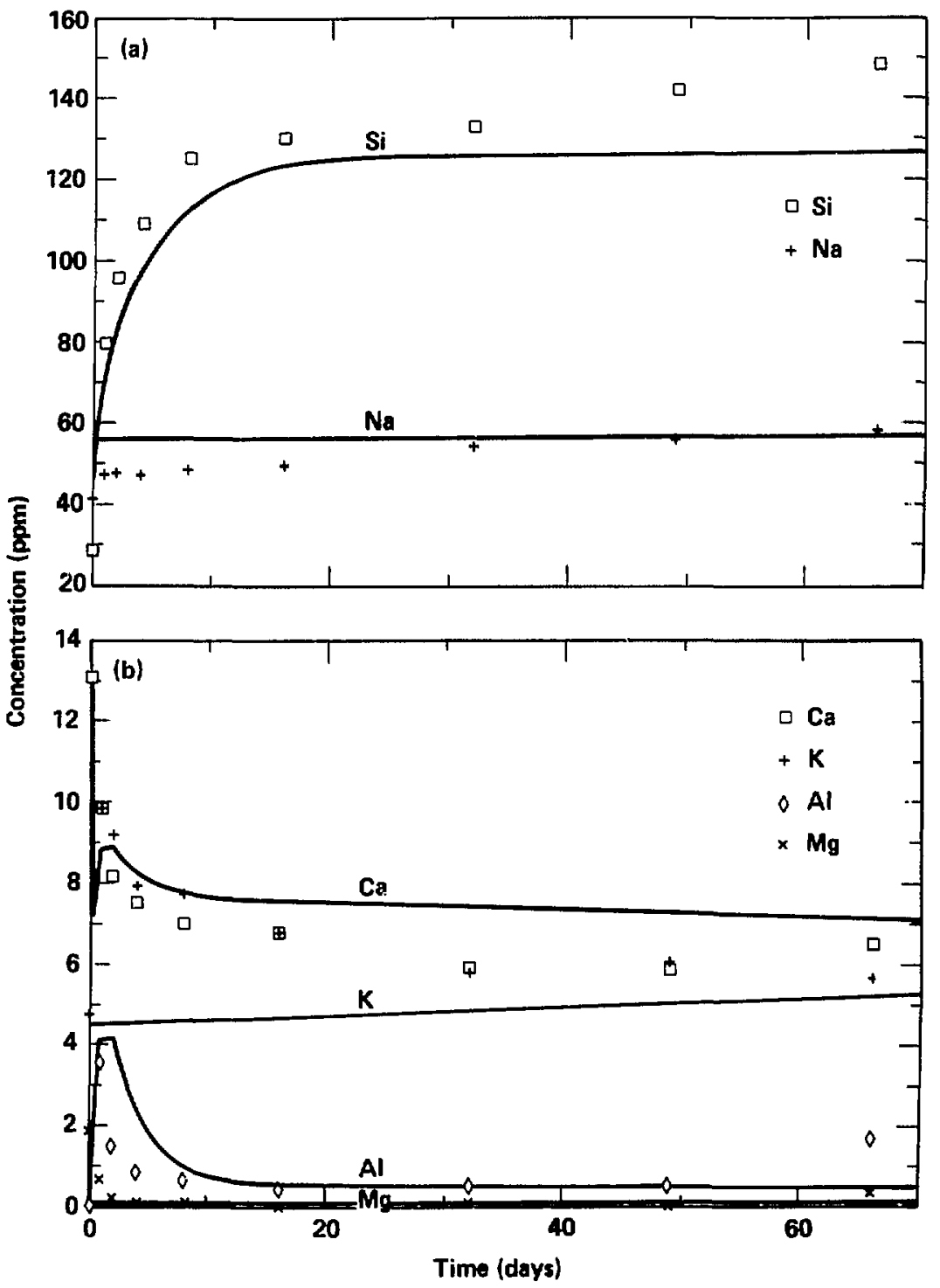

Figure 5a. Concentration of $S i$ and $v a$ vs time for $150^{\circ} \mathrm{C}$ Tpt crushed-tuff simulation symbols represent analytical values from Knauss et al. (1985a). 5b. Concentration of $\mathrm{Ca}, \mathrm{K}, \mathrm{Al}$, and $\mathrm{Mg}$ vs time for $150^{\circ} \mathrm{C}$ Tpt crushed-tuff simulation. 
(Fig. 6). The steady state concentrations of the major $\mathrm{J}-13$ components are listed in Table 4. The resulting open-system ol is approximately 8.5 , thus preventing the formation of calcite. The silica concentration is controlled by clinoptilolite and is maintained at a level of $146 \mathrm{ppm}$. As cristobalite equilibrium is reached, its subsequent dissolution rate is set to zero. At the conclusion of the run, the three minor components in the core wafer were exhausted, and 20 of the sanidine was destroyed. The increase in $\mathrm{Na}$ concentration from 41 to $74 \mathrm{ppm}$ over the reaction interval is related to the dissolution of the sanidine component. In a similar manner the increase in Al concentration to $23 \mathrm{ppm}$ can also be related to sanidine dissolution. The concentration of $\mathrm{Ca}$ in solution is essentially negligible and that for $\mathrm{K}$ is very low, 1.7 ppm.

The cation concentrations are controlled by the formation of secondary

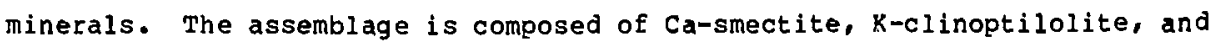
Ca-clinoptilolite at the end of the run. Only k-clinoptilolite was not present in the assemblage observed after 66 days. Because the clinoptilolite phases vary in composition, improved solid solution models under development

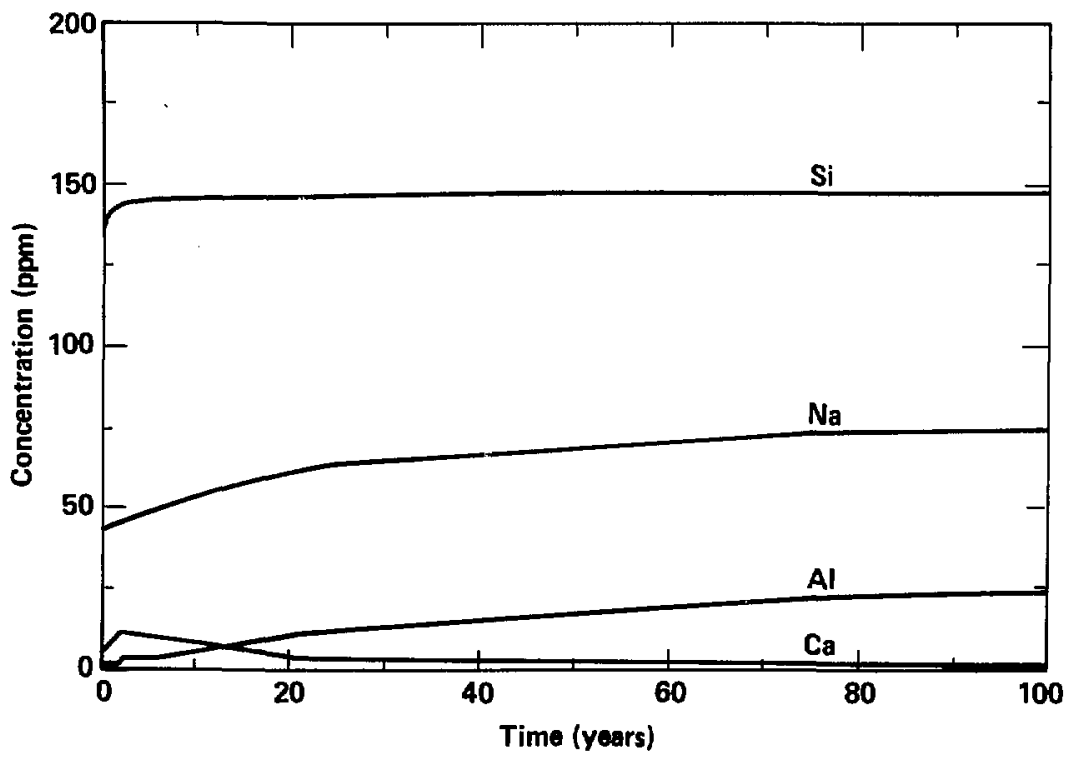

Figure 6. Concentration vs time plot for $150^{\circ} \mathrm{C}$ Tpt core-wafer 100-year simulation. 
Table 4. Steady state J-13 composition

(open system $150^{\circ} \mathrm{C}$, 100 years; see text).

\begin{tabular}{lc}
\hline gH & Component \\
\hline 6.4 & 74.4 \\
$\mathrm{Na}$ & 1.65 \\
$\mathrm{Ka}$ & 0.007 \\
$\mathrm{Mg}$ & 0.0 \\
$\mathrm{Al}$ & 23.7 \\
$\mathrm{Si}$ & 146.8 \\
$\mathrm{NO}_{3}$ & 9.1 \\
$\mathrm{~F}$ & $i .6$ \\
$\mathrm{Cl}$ & 6.7 \\
$\mathrm{HCO}_{3}$ & 7.4 \\
$\mathrm{SO}_{4}$ & 17.9 \\
\hline
\end{tabular}

for the $E Q 3 / 6$ codes hopefully will permit better modeling of the dissolution of tuff. This simulation has shown that data obtained from relatively short laboratory experiments may be sufficient for extrapolation to longer times. Additional EQ6 runs were made to evaluate the buffering capacity of J-13 water over the 100-year interval. No changes were observed in either the solution concentrations or the secondary mineral assemblage as a result of varying the $\mathrm{pH}$ and $\mathrm{pCO}_{2}$ within a range observed for field analyses of $\mathrm{J}-13$ water. It appears that the existing mineral assemblage is capable of effectively buffering the water/mineral system (see ogard and Kerrisk, 1984).

All EQ6 simulations are calculated on a per-kg-of-solution basis. For the $150^{\circ} \mathrm{C}$ core-wafer experiment, the rock/water ratio is $2 \mathrm{~g}$ of rock per $200 \mathrm{ml}$ of solution. To relate this to a repository environment in the unsaturated zone, the water source has to be accounted for. An upper bound of one millimeter per year has been estimated from precipitation infiltration of 0.5 to $4.5 \mathrm{~mm}$ measured at Yucca Mountain (Montazar and Wilson, 1984). Using this value as the fluid source, a cubic centimeter of rock would come in contact with $200 \mathrm{ml}$ of water over a period of 2,000 years. Thus, under these conditions, the long-term reaction interval of 100 years would actually 
correspond to 200,000 years of repository existence at $150^{\circ} \mathrm{C}$. Fluid temperatures will probably not $\mathrm{r}$ ise above $120^{\circ} \mathrm{C}$, so these steady-state conditions are at most a preliminary upper bound on $\mathrm{J}-\mathrm{l} 3$ compositional variation.

\section{SUMMARY}

The dissolution of Tpt in J-13 water can be reasonably approximated by using a simplified host-rock recipe containing six phases and an average $\mathrm{J}-13$ composition. A closed-system environment at $150^{\circ} \mathrm{C}$ can be simulated by imposing a minimum of number of constraints on the $\mathrm{EQ}_{\mathrm{O}} / 6$ input parameters. Composition changes observed in $\mathrm{J}-13$ solution compositions reacted with Tpt at $150^{\circ} \mathrm{C}$ indicate that the 1 imiting solution composition is determined by the formation of secondary phases. These phases have been identified by EQ6 to be cristobalite, Ca-smectite, and Ca-clinoptilolite. The existence of cristobalite and a smectite/illite phase has been corroborated by direct observation of reacted core wafers. The current EQ3/G data base represents these phases as idealized compositions from estimated thermodynamic data. EQ6 treats the dissolution of reactant phases according to user-specified rate laws and rate constants. The rate constants for each phase in the model are constrained to yield negligible dissolution of the starting host rock. This constraint also serves to offset the uncertainties associated with individual rate constants compiled srom different sources. This procedure ensures that computed host-rock dissolution will coincide with experimental observations (Knauss and Beiriger, 1985b).

Preliminary EQ6 results indicate further experimentation is necessary before an interpretation of the processes controlling the solution composition can be made. For example, the initial steep rise in silica concentration observed in crushed-tuff experiments may be attributed to the presence of a large fraction of ultrafine material created by the grinding technique used in the sample preparation. This ultrafine fraction that has been referred to as a form of "disturbed material" by Holdren and Berner (1979). It consists of particles dissolved rapidy in solution so as to initially increase the rate of dissolution. As these particles disappear the dissolution rate decreases and levels off. Additional experiments using pretreated crushed tuff that has 
had the ultrafine fraction removed should identify any increase in solution concentration by the fine fraction.

'A similar initial increase is observed in the potassium concentration associated with the crushed-tuff samples. The reason for the potassium increase is more complex, because the same effect is also observed in the core-wafer solutions. Although the amount of starting material in the crushed experiments was more than three times greater than that in the core-wafer experiments, the initial increases in solution concentration are about the same. If this effect is controlled by the dissolution of fines, it should be sensitive to the total amount of sample used in the experiment. Without additional data, these results seem to suggest that the potassium increase may be controlled thermodynamically rather than kinetically. Additional crushed-tuff experiments using various rock/water ratios should clarify the relationship between the initial behavior observed for silica and potassium. Comparison of $E_{Q 3} / 6$ results for 150 and $250^{\circ} \mathrm{C}$ experiments indicates that the data base cannot adequately model this system at $250^{\circ} \mathrm{C}$. Future data base work should include smectite and zeolite compositions that are more similar to those observed both in the tuff and those formed as reaction products (i.e., dachiardite). The modeling of $250^{\circ} \mathrm{C}$ experiments is mainly for validation purposes. Therefore, $\mathrm{EQ}^{3 / 6}$ data base activities should concentrate on improving the thermodynamic data for the smectite phases. For instance, the composition of illite in the current data base is a magnesium variety. The geochemical systesn being modeled at Yucca Mountain is very low in magnesium. As a result, illite does not form as an EQ6 product phase, although it may be a minor secondary phase in the natural system. The addition of other montmorillonite compositions to the data base may significantly change the calculated amount of smectite to zeolite predicted by $E Q 6$ at $150^{\circ} \mathrm{C}$. The $E Q 6$ results indicate that the formation of secondary phases is important when modeling the solution compositions in this system. Since the thermodynamic data for most of these phases are estimated, an improved data base is important for more complete modeling of this system.

At the time of these calculations, the addition of several rate laws to handle precipitation kinetics was under development. These changes will be available in the next release version of the EQ3/6 package. 


\section{BIBLIOGRAPHY}

Aagard, P., and H. C. Helgeson (1983), "Activity/Composition Relations Among Silicates and Aqueous Solutions. II. Chemical and Thermodynamic Consequences of Ideal Mixing of Atoms on Homological Sites in Montmorillonites, Illites, and Mixed-Layer Clays," Clay Clay Miner. 31 , 207-217.

Benson, L. V., J. H. Robison, R. K. Blankennagel, and A. E. Ogard (1983), Chemical Composition of Ground water and the Locations of Fermeable zones in the Yucca Mountain Area, Nevada, U.S. Geological Survey, Open-File Report 83-854.

Claassen, H. C., and A. F, White (1979), "Application of Geochemical Kinetic Data to Ground-Water Systems--A Tuffaceous-Rock system in Southern Nevada," Chemical Modeling in Aqueous Systems, E. A. Jenne, Ed. (American Chemical society), Symposium Series No. 93, 771-794.

Claassen, H. C. (1973), Water Quality and Physical Characteristics of Nevada Test Site Water-Supply Wells, U.S. Geological Survey, USGS-474-15B. Claassen, H. C. (1983), Sources and Mechanisms of Recharge for Ground Water in the West-Central Amargosa Desert, Nevada--A Geochemical Interpretation, U.S. Geological Survey, Open-File Report 83-542.

Daniels, W. R., K, Wolfsberg, R. S. Rundberg, A. E. Ogard, J. F.Kerrisk, C. J. Duffy et al. (1982), Summary Report on the Geochemistry of Yucca Mountain and Environs, Los Alamos National Laboratory, Los Alamos, NM, LA-9328-MS .

Davis, S. N. (1964), "Silica in steams and Ground water," Am. J. Sci. 262, $870-891$.

Delany, J. M., and T. J. Wolery (1984), Fixed-Fugacity option for the EQ6 Geochemical Reaction Path Code, Lawrence Livermore National Laboratory, Livermore, CA, UCRL-53598.

Delany, J. M., I. Puigdomerech, and T. J. Wolery (1986), Precipitation Kinetics Option for the EQ6 Geochemical Reaction Path Code, Lawrence Livermore National Laboratory, Livermore, CA, UCRL-53642.

Freeze, R. A., and J. A. Cherry (1979), Groundwater (Prentice-Hall, Inc., Englewood Cliffs, NJ). 
Garrels, R. M. (1984), "Montmorillonite/Illite Stability Diagrams," Clay Clay Miner. $32,161-166$.

Guzowski, R. V., F. B. Nimick, M. D. Siefel, and N. C. Finley (1983), Repository Site Data Report for Tuff, Yucca Mountain, Nevada, Sandia National Laboratories, Albuquerque, NM, NUREG/CR-2937.

Helgeson, H. C., W. M. Murphy, and P. Aagard (1984), "Thermodynamic and Kinetic Constraints on Reaction Rates Among Minerals and Aqueous Solutions. II. Rate Constants, Effective Surface Area, and the Hydrolysis of Feldspar," Geochim. Cosmochim. Acta 48, 2405-2432. Holdren, G. R., Jr., and R. A. Berner (1979) "Mechanism of Feldspar Weathering. I. Experimental studies," Geochim. Cosmochim. Acta 43 , 1161-1171.

Kerrisk, J. F. (1983), Reaction-Path Calculations of Groundwater Chemistry and Mineral Formation at Rainier Mesa, Nevada, Los Alamos National Laboratory, Los Alamos, NM, LA-9912-MS.

Knauss, K. G. $\left(1984 \mathrm{z}_{1}\right)$, Hydrothermal Interaction Studies of Bullfrog Member Tuff Core Wafers in $\mathrm{J}-13$ water at $150^{\circ} \mathrm{C}$ : Quantitative Analyses of Aqueous and Solid Phases, Lawrence Livermore National Laboratory, Livermore, CA, UCRL -53521 .

Knauss, K. G. (1984b), Petrologic and Geochemical Characterization of the Topopah Spring Member of the Faintbrush Tuff: Outcrop Samples Used in Waste Package Experiments, Lawrence Livermore National Laboratory, Livermore, CA, UCRL-53558.

Knauss, K. G., and W. J. Beiriger (1984a), Report on Static Hydrothermal Alteration studies of Topopah Spring Tuff wafers in $\mathrm{J}-13$ water at $150^{\circ} \mathrm{C}$, Lawrence Livermore National Laboratory, Livermore, CA, UCRL-53576. Knauss, K. G., and W. J. Belriger (1984b), "Dachiardite Formation by Hydrothermal Alteration of a Devitrified High-Silica Rhyolite," Geological Soc. Am. 16, 561 (abst. with prosram). Knauss, K. G., and T. J. Wolery (1985), "Dependenc. of Albite Dissolution Kinetics on $\mathrm{pH}$ and $\mathrm{Time}$ at $25^{\circ} \mathrm{C}$ and $70^{\circ} \mathrm{C}$, "Geochim. Cosmochimi. Act." (in press).

Knauss, K. G., W. J. Beiriger, and D. W. Peifer (1985a), Hydrothermal Interaction of Crushed Topopah Spring Tuff and $\mathrm{J}-13$ Water at $90^{\circ} \mathrm{C}, 150^{\circ} \mathrm{C}$, and $250^{\circ} \mathrm{C}$ Using Dickson-type Gold-Cell Rocking Autoclaves, Lawrence Livermore National Laboratory, Livermore, CA, UCRL-53630. 
Knauss, K. G., W. J. Beiriger, D. W. Peifer, and A. Piwinski i (1985b),

Reaction of Solid Wafers to Topopah Spring Tuff with J-13 and Distilled

Water at $90^{\circ} \mathrm{C}, 150^{\circ} \mathrm{C}$, and $250^{\circ} \mathrm{C}$ in Dickson-Type Gold-Cell Rocking

Autoclaves 1. Short-Term Experiments, Lawrence Livermore National

Laboratory, Livermore, CA, UCKL-53645.

Knauss, K. G., J. M. Delany, W. J. Beiriger, and D. W. Peifer (1984),

"Hydrothermal Interaction of Topopah spring Tuff with J-13 water as a

Function of Temperature," Mater. Res. Soc. Symp. Proc., Boston, MA,

Nov. 25-30, 1984 .

Lasaga, A. C. (1981), "Transition State Theory," A. C. Lasaga and

R. J. Kirkpatrick, Eds., Kinetics of Geochemical Processes: Reviews in

Mineralogy $8,135-170$.

Lin, F. C., and C. V. Clemency (1981), "Dissolution Kinetlcs of Phlogopite. I.

Closed Systen, Clay Clay Miner. 29, 101-106.

Moore, D. E., C. A. Morrow, and J. D. Byerlee, (1984), Changes in

Permeability and Eluid Chemistry of the Topopah spring Member cf the

Paintbrush TuEf (Nevada Test Site) When Held in a Temperature cradient:

Summary of Results, Lawrence Livermore National Laboratory, Livermore,

CA, UCRL-15620.

Montazar, P., and W.E. Wilson, (1984), Conceptual Hydrologic Model of Flow in

the Unsaturated Zone, Yucca Mountain, Nevada, U.S. Geological survey,

Water-Resources Investigations Report, 84-4345.

Ogard, A. E., and J. F. Kerrisk (1984), Groundwater Chemistry Along Flow Paths

Between a Proposed Repository Site and the Accessible Environment,

Los Alamos National Laboratory, Los Alamos, NM, LA-10188-MS.

Oversby, V. M. (1982), Leach Testing of Waste Forms, Interrelationship of Iso

and MCC Type Tests, Lawrence Livermore National Laboratory, Livermore,

CA, UCRL-87621.

Oversby, V. M. (1984a), Reaction of the Topopah Spring ruff with J-13 Wel1

Water at $90^{\circ} \mathrm{C}$ and $150^{\circ} \mathrm{C}$, Lawrence Livermore National Laboratory,

Livermore, CA, UCRL-53552.

Oversby, V. M. (1984b). Reaction of the Topopah Spring Tuff with J-13 Well

Water at $120^{\circ} \mathrm{C}$, Lawrence Livermore National Laboratory; Livermore, CA, UCRL -53574 . 
oversby, V. M., and K. G. Knauss (1983), Reaction of Bullfrog Tuff with J-13 Well Water at $90^{\circ} \mathrm{C}$ and $150^{\circ} \mathrm{C}$, Lawrence Livermore National Laboratory, Livermore, CA, UCRL-53442.

Rimstidt, J. D., and H. L. Barnes (1980), The Kinetics of Silica-Water

Reactions," Geochim. Cosmochim. Acta 44, 168:-i699.

Robison, J. H. (1984), Ground-Water Level Data and preliminary

Potentiometric-Surface Maps, Yucca Mountain and Vicinity, Nye County, Nevada, U.S, Geological Survey, Water-Resources Investigations Report 84-4197.

Roseboom, E. H. (1983), Disposal of High-Level Nuclear waste Above the water

Table in Arid Regions, U.S. Geological survey, Circular 903.

silling, S. A. (1983), Final Technical Position on Documentation of Computer Codes for High-Level Waste Management, Division of Waste Management, U.S. Nuclear Regulatory Commission, NUREG-0856.

Thordarson, W. (1983), Geohydrologic Data and Test Results from Well J-13,

Nevada Test Site, Nye County, Nevada, U.S. Geological survey,

Water-Resources Investigations Report 83-4171.

Tyler, L. D. (1982), Memorandum from L. D. Tyler of Sandia National Laboratory to D. Vieth of Waste Management Project office (WMPO), Nevada Nuclear Waste Storage Investigations (NNWSI), $9 \mathrm{July} 1982$,

Vieth, D. L. (198?), "Nevada Nuclear Waste Storage Investigations Project Overview." Proceedings of the 1982 National Waste Terminal storage Progran Information Meeting, U.S. Department of Energy.

Walter, L. M., and J. W. Morse (1985), "The Dissolution Kinetics of Shallow Marine Carbonates in Seawater: A Laboratory study," Geochim. Cosmochim. Acta $49,1503-1513$.

Warren, R. G., F. M. Byers, F. A. Caporuscio (1984), Petrography and Mineral Chemistry of Units of the Topopah Spring, Calico Hills and Crater Flat Tuffs, and Older Volcanic Units, with Emphasis on Samples from Drill Hole USW G-1, Yucca Mountain, Nevada Test Site, Los Alamos National

Lä̀oratory, Los Alamos, NM, LA-10003-MS.

Waters, A. C., and P. R. Carroll, Eds. (1981). Preliminary stratigraphic and Petrologic Characterization of Core Samples from USW-Gl, Yucca Mountain, Nevada, Los Alamos National Laturatory, Los Alamcs, NM, LA-8840-MS. 
White, A. F., and H. C. Claassen (1979), "Dissolution Kinetics of Silicate Rocks--Application to solute Modeling," E. A. Jenne, Ed., Chemical Modeling in Aqueous Systems, American Chemical Society symposium Series, No. 93, pp. 447-474.

White, A. F. (1979), Geochemistry of Ground Water Associated with Tuffaceous Rocks, Oasis Valley, Nevada, U.S. Geological Survey, Professional Paper $712-E$.

White, A. F., and H. C. Claassen (1980), "Kinetic Model for the Short-Term Dissolution of a Rhyolitic Glass," Chem. Geol. 28, 91-109.

White, A. F., H. C. Claassen, and L. V. Benson (1980), The Effect of Dissolution of Volcanic gliss on the Chemistry in a Fuffaceous Aquifer,

Rainier Mesa, Nevada, U.S. Geological Survey, Water-Supply Paper, 1535-2. Wolery, T. J. (1979), Calculation of Chemical Equilibrium Between Agueous Solution and Minerals: The EQ3/6 Software Package, Lawrence Livermore National Laboratory, Livermore, CA, UCRL-52658. Wolery, T. J. (1983), EQ3NR, A Computer Prugram for Geochemical Aqueous Speciation-Solubility Calculacions: User's Guide and Documentation, Lawrence Livermore National Laboratory, Livermore, CA, UCRL-53414. Wolery, T. J., D. J. Isherwood, K. J. Jackson, J, M. Delany, and I. Puigdomenech (1984), "EQ3/6 status and Applications," The Application of Geochemical Models to High-Level Nuclear Waste Repository Assessment Proceedings (Oak Ridge National Laboratory, Oak Ridge, TN); available from Lawrence Livermore National Laboratory, Livermore, CA, UCRL-91884. Wolery, T. J. (1985a), EQ6, A Computer Program for Reaction-Path Modeling of Aqueous Geochemical Systems: User's Guide and Documentation, Lawrence Livermore National Laboratory, Livermore, $C A$, (in preparation). Wolery, T. J. (1985b), MCRT, A Data Base Building Code for the EQ $3 / 6$

Geochemical Modeling software Package: User's Guide and Documentation, Lawrence Livermore National Laboratory, Livermore, CA, (in preparation). Wolery, T. J. (1986), Some Forms of Transition state Theory, Including

Non-equilibrium steady state Forms, and Their Application in

Geochemistry, Lawrence Livermore National Laboratory, Livermorf, CA, (UCRL-94221). 
Wolfsberg, K., B. P. Bayhurst, B. H. Crowe, W. R. Daniels, B. R. Erdal, and R. O. Lawrence (1979), sorption-Desorption studies on Tuff. 1. Initial Studies with Samples from the J-13 Drill Site, Jackass Flats, Nevada.

Wollenberg, H..A., J. S. Y. Wang, and G. Korbin (1983), An Appraisal of Nuclear Waste Isolation in the Vadnse zone in Arid and Seiniaris Regions (with Emphasis on the Nevada Test Site), Lawrence Berkeley Laboratory, Berkeley, CA, LBL-15010. 
Appendix A. Constants used to construct theoretical rock recipes.

\begin{tabular}{lcc}
\hline \multicolumn{1}{c}{ Phase } & Density & Molecular weight \\
\hline Cristobalite & 2.3343 & 60.084 \\
Alkali feldspar & 2.5829 & 271.771 \\
Quartz & 2.6483 & 60.084 \\
Plagioclase & 2.6361 & 266.151 \\
Mg-beidellite & 2.8392 & 363.96 \\
Biotite & 3.0896 & 471.197 \\
\hline
\end{tabular}


input file name: db800

creator: j. delany

analysis of waters from dixon bomb experimeñts with topopah springs tuff (tpt) polished core wafer, reported by $k$. knauss $(5 / 14 / 84)$ reference 0 days at $150 \mathrm{c}$ and 50 bar with a rock/water ratio of $34.72 \mathrm{~g} / \mathrm{kg}(7.0161 \mathrm{~g} / 201.64 \mathrm{ml})$.

experimental. notes: wptptobs

$$
\text { used langhorst 10x dilution for si and } \mathrm{ca} \text {, only }
$$

endit.

tempc $=$

$$
\text { gl-1232 c.w. }
$$

rho $=$ fep $=$ tolbt $=$ iterm $x=$ iopt $1-10=$ iprnt $1-10=$ idbugl $-10=$ uebal = nxmod $=3$ species $=$ quart. $z$ type $=1$ species = chalcedony type $=1$ species $=$ tridymite type $=1$ ht nat $k+$ calt mgit alt+t $\operatorname{sio2}(a q)$ hco3$f-$ clno3endit.
25. $\begin{array}{cc}1.0 & \text { tdspkg }= \\ -0.68 & \text { uredox }= \\ 0 . & \text { toldl }=\end{array}$

o. tolsat $=$ 0 .

D. $\quad t d s p l=$

$\begin{array}{llllllllll}0 & 0 & 0 & 0 & 0 & 0 & 0 & 0 & 0 & 0\end{array}$

$\begin{array}{lllllll}0 & 0 & 0 & 0 & 0 & 0 & 0\end{array}$

uacion= nat

0.

uacion= nat 
APPENDIX C. Sample EQ6 Input File for Core-Wafer Experiment

This sample EQ6 input file is for the run at $150^{\circ} \mathrm{C}$ and the rock recipe corresponding to crushed tuff generated using the data in Tables 1 thru 4. The file itself is all lower case, as shown. The line beginning with input file: db800 is the beginning of the PICKUP file written by EQ3NR.

input file name: $i 6 \mathrm{cw} 150$ revised $02 / 15 / 85$ creator: $j$. delany

reaction of j-13 water using Tpt core-wafer recipe at $150 \mathrm{c}$.

effective surface area estimated to be 20 percent of total surface area.

nxmod supression option imposed on

1. silica phases (see text)

2. pyrophyllite (below $250 \mathrm{c}$ )

3. k-feldspar (sanidine is host-rock phase) thermodynamic data estimated for illite and clinoptilolite were reevaluated and stabilized slightly.

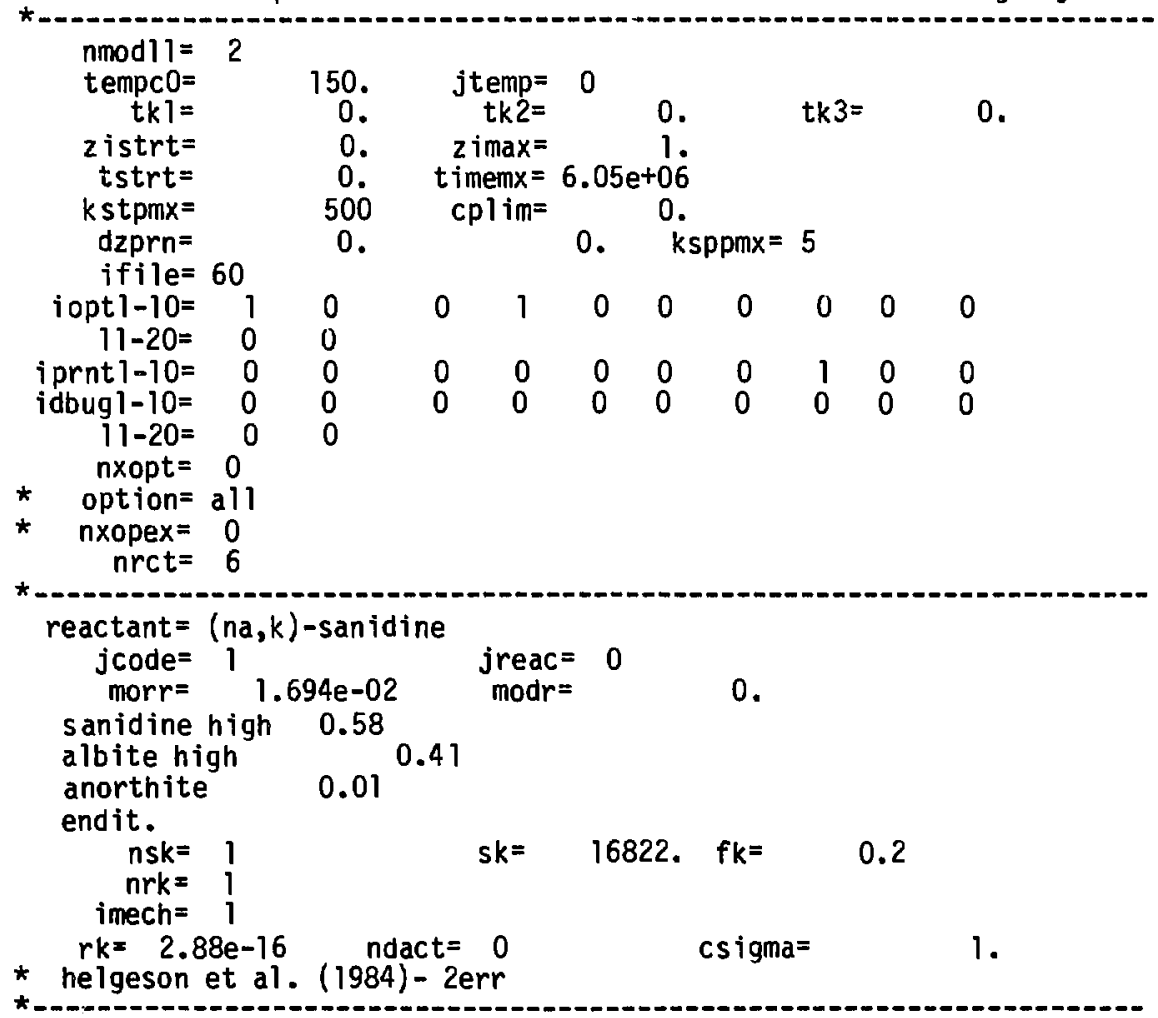




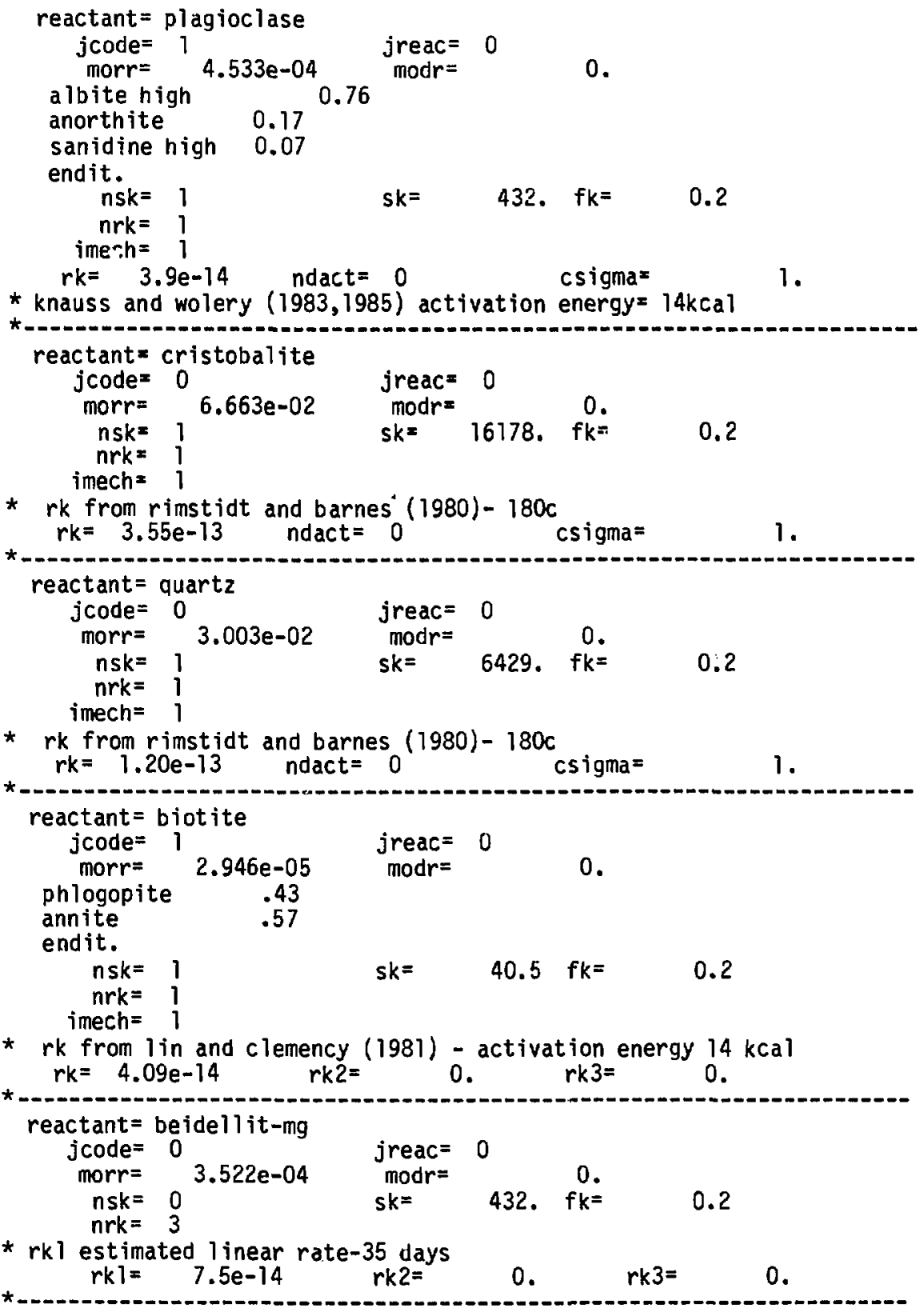




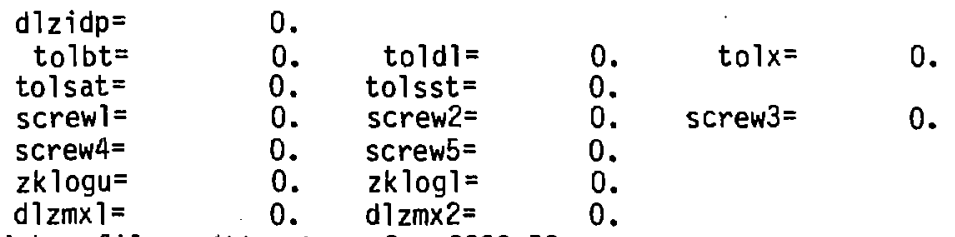

* pickup file written by eq3nr.3230s53

* supported by eqlib.3230u02

input file name: db800 created 10/20/84 creator: j. delany

analysis of $j-13$ water run at day zero.

reported by $k$. knauss $(5 / 14 / 84)$.

hco3- average of 13 analyses

(co2 analyzer, reported $1 / 14 / 85$ )

reference: knauss, k., 1985,

: lawrence livermore

national laboratory, ucrl-in preparation.

endit.

uacion $=$ nat

tempc $i=2.50000 \mathrm{e}+01$

nxmod $=7$

species $=$ quartz

type $=1 \quad$ option $=-1 \quad \times 1 \mathrm{kmod}=0$.

species = chalcedony

type $=1$

species $=$ tridymite

option $=-1 \quad \times 1 \mathrm{kmod}=0$.

type $=1 \quad$ option $=-1 \quad \times 1 \mathrm{kinod}=0$.

$\begin{gathered}\text { species } \\ \text { type }=\end{gathered}=$ pyrophyllite $\quad$ option $=-1 \quad x /$ knod $=0$.

species $=$ maximum microcline

type $=1$ 


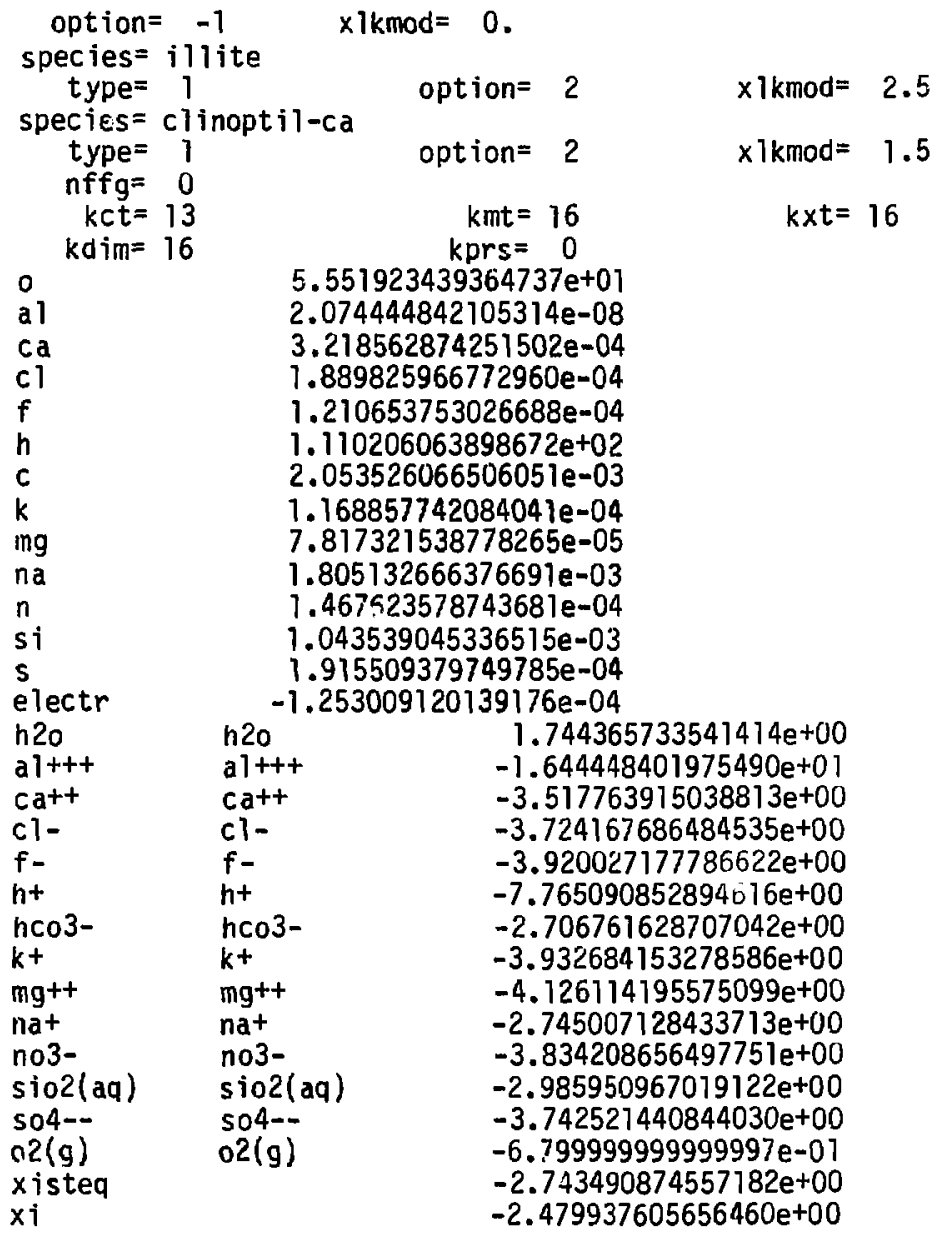

